\title{
ANALISIS KETERKAITAN HARGA ANTAR KELOMPOK KOMODITAS PEMBENTUK INFLASI DI SUMATERA BARAT
}

\author{
Gaffari Ramadhan ${ }^{1}$
}

\begin{abstract}
This study analyzes the correlation and the interaction among commodity groups which determine the inflation rate in West Sumatera. Using the monthly data from January 2002 to December 2008, the estimation applies the Vector Error Correction Model (VECM) in order to analyze the dynamics of commodity prices in the model.

The results show some groups have significant contributions in determining other group prices. We found that the volatility of Prepared Food, Drink, Cigarette, and Tobacco is affected by Food group, Transportation, Communication and Financial Services. All commodity group is mostly affected by its own movement, especially for the high regulated prices group; Water, Electricity, and Fuel group including Housing.

This paper underlines that in controlling regional inflation, the partial effort by focusing only on the basket goods which gives the highest contribution to the regional inflation (i.e. foodstuff and prepared food) is not effective when the region faces high volatility in other basket goods (i.e. transportation). The price determining of basket goods is a simultaneous process, and controlling the regional inflation needs greater concern to all goods. The government intervention on the price setting is also one of the important parts in causing the volatility of the basket goods.
\end{abstract}

JEL Classification: C32, E31, R10.

Keywords: Consumer Price Index, regional inflation, vector error corection model, impulse response, variance decomposition.

\footnotetext{
1 Peserta Pendidikan Calon Pegawai Muda (PCPM) Angkatan XXVIII untuk Peneliti Ekonomi Muda Bank Indonesia. Versi awal paper ini telah dipresentasikan pada Focus Group Discussion pengendalian inflasi Propinsi Sumatera Barat di Padang, 19 Februari 2009.
} 


\section{PENDAHULUAN}

\section{I.1. Latar Belakang}

Inflasi sebagaimana menunjukkan pergerakan harga yang terjadi dalam suatu perekonomian tentu dipengaruhi oleh berbagai determinan. Dalam Gordon (1997) pendekatan determinan inflasi dapat dijelaskan melalui inflasi permintaan, inflasi penawaran, dan ekspektasi inflasi. ${ }^{2}$ Berdasarkan Survei Biaya Hidup (SBH) tahun 2007 yang dilakukan oleh Badan Pusat Statistik (BPS), perhitungan inflasi dibentuk melalui sejumlah komoditas yang dikelompokkan secara umum menjadi beberapa kelompok seperti: kelompok bahan makanan; kelompok makanan jadi, minuman, rokok dan tembakau; kelompok perumahan, air, listrik, dan bahan bakar; kelompok sandang; kelompok kesehatan; kelompok pendidikan, rekreasi, dan olahraga; kelompok transportasi, komunikasi, dan jasa keuangan.

Studi ini dilakukan untuk mengetahui bagaimana pola pergerakan masing-masing kelompok komoditas pembentuk inflasi tersebut antara satu kelompok komoditas dengan kelompok komoditas lainnya. Bagaimanapun, pembentukkan harga suatu komoditas dalam suatu perekonomian tentunya dipengaruhi oleh harga komoditas lainnya. Dalam proses produksi suatu komoditas pola penetapan harganya dipengaruhi oleh input-input yang berperan dalam proses produksi output tersebut. Dengan demikian, studi ini mencoba melihat seberapa besar keterkaitan (linkage) antar kelompok komoditas pembentuk inflasi di Sumatera Barat.

Studi ini mencoba melihat bagaimana harga masing-masing kelompok komoditas pembentuk inflasi bergerak secara acak dan berperan sebagai variabel-variabel endogen yang membuka pengaruh pembentukan harganya oleh harga pada kelompok komoditas lain. Seperti pada Clements dan Izan (1987) dengan melakukan estimasi pada komoditas pembentuk indeks harga konsumen secara bersamaan untuk melihat bagaimana pola pergerakan dan keterkaitannya. Dengan demikian, berangkat dari hasil tersebut, maka dapat dilihat bagaimana fenomena ekonomi yang terjadi dibalik pola keterkaitan antar harga pada berbagai kelompok komoditas pembentuk inflasi. ${ }^{3}$

Seperti halnya Stock dan Watson (2005), juga menggunakan data harga indeks kelompok barang pembentuk indeks harga konsumen untuk memperkaya analisis keterkaitan antar variabel ekonomi secara dinamis. Dengan menggunakan model Vector Auto-Regression (VAR), Stock

2 Robert J. Gordon, "The Time-Varying NAIRU and its Implications for Economic Policy". Journal of Economic Perspectives - Vol. 11, No.1, 1997, hlm. 11-32.

3 Kenneth W. Clements dan H.Y. Izan, "The Measurement of Inflation: A Stochastic Approach," Journal of Business and Economic Statistics, Vol. 5, No. 3 (Jul, 1987), hlm. 339-350 
dan Watson (2005) memasukkan sejumlah time series tersebut untuk melihat keterkaitan bukan hanya antar kelompok komoditas tersebut namun juga dengan sejumlah variabel makroekonomi lainnya. ${ }^{4}$

Brodjonegoro, Felianty, dan Gitaharie (2005) melakukan studi mengenai inflasi daerah dengan menggunakan analisis variance decompostition melalui metode VAR (Vector Autoregression) mencoba melihat determinan inflasi di daerah apakah didominasi oleh faktorfaktor moneter atau non-moneter. Hasil estimasi secara keseluruhan menunjukkan bahwa mayoritas tingkat inflasi di daerah lebih banyak disebabkan oleh faktor-faktor non-moneter. Selain itu, dalam studi tersebut juga melakukan beberapa analisis di mana menyimpulkan bahwa kondisi infrastruktur, tingkat efisiensi perdagangan, dan kebijakan atau regulasi pemerintah daerah menjadi faktor yang juga turut mempengaruhi inflasi daerah. ${ }^{5}$

Wimanda (2006) dalam studinya mengenai inflasi regional di Indonesia mengemukakan bahwa setelah krisis ekonomi tingkat volatilitas inflasi di daerah menjadi lebih tinggi. Inflasi pada kelompok transportasi memberikan kontribusi besar dalam pembentuk inflasi di daerah, hal ini juga tidak terlepas dari pengaruh harga bahan bakar. Kemudian, peningkatan harga pada kelompok komoditas tersebut berdampak pada inflasi di kelompok bahan makanan, makanan jadi, dan perumahan. Selain itu, antara inflasi-inflasi daerah dengan inflasi nasional tidak menunjukkan adanya konvergensi sehingga pola pergerakannya seringkali berbeda dari pergerakan inflasi nasional. ${ }^{6} \mathrm{Hal}$ inilah yang dapat mengakibatkan kebijakan moneter tidak secara penuh efektif dalam menekan laju inflasi di daerah. Seperti pada Carlino dan Defina (1998), menyatakan bahwa secara teoritis kebijakan moneter merupakan kebijakan yang bersifat skala nasional. Namun demikian dalam realitasnya terjadi divergensi daerah dalam merespon shocks dari variabel agregat ekonomi tersebut. ${ }^{7}$

Perkembangan harga-harga yang ditentukan oleh pemerintah (adminitered prices) seperti halnya bahan bakar minyak (BBM), tentu memiliki dampak tersendiri terhadap harga pada sektor transportasi. Kemudian, hal ini akan berimbas pada komoditi lain yang menggunakan bahan bakar minyak dalam proses produksi maupun distribusinya. Seperti dalam Majardi (2002),

4 Studi ini tidak hanya menggunakan variabel kelompok-kelompok komoditas pada IHK, namun juga pada Indeks Produksi Industri (Industrial Production Indeks), dan Indeks Harga Perdagangan Besar (Producer Price Index). Lihat selengkapnya pada James H. Stock dan Mark W. Watson, "Implications of Dynamic Factor Models for VAR Analysis," Working Paper 11467, National Bureau of Economic Research, Juni 2005.

5 Untuk selengkapnya bisa lihat Bambang P.S. Brodjonegoro, Telissa Falianty, dan Beta Y. Gitaharie, "Determinant Factors of Regional Inflation in Decentralized Indonesia," Journal of Economics and Finance in Indonesia, Vol. 53 (1), pp. 1-31.

6 Lihat selengkapnya dalam Rizki E. Wimanda, "Regional Inflation in Indonesia: Characteristic, Convergence, and Determinants," Bank Indonesia Working Paper, No.13, Oktober 2006.

7 Lihat selengkapnya pada Gerald Carlino dan Robert Defina, "The Differential Regional Effects of Monetary Policy," The Review of Economics and Statistics, Vol. 80, No.4, November 1998. pp.572-587. 
perkembangan harga BBM yang merupakan salah satu komponen administered prices seringkali merupakan penyebab utama tingginya perkembangan harga barang administered tersebut dan perkembangan inflasi IHK pada umumnya. ${ }^{8}$

Dari segi barang hasil komoditas pertanian, tentu saja banyak faktor yang mempengaruhi penentuan harganya, mulai dari faktor musim, cuaca, hingga kelancaran jalur distribusi dan pasokan. Shock harga yang terjadi pada komoditas ini yang masuk di dalam kelompok bahan makanan, akan secara langsung dirasakan pada kelompok komoditas lain yang menggunakan hasil komoditas pertanian atau kelompok bahan makanan tersebut sebagai bahan bakunya.

Jadi pertanyaan yang mengemuka adalah, apakah terjadi keterkaitan antar harga kelompok-kelompok komoditas pembentuk inflasi? Bagaimana pengaruh peningkatan harga pada suatu kelompok komoditas tertentu terhadap pergerakan harga di kelompok komoditas lainnya? Dan seberapa besar kontribusi pengaruh dari harga suatu kelompok komoditas terhadap shock pergerakan harga di kelompok komoditas lainnya?

Oleh karena itu, salah satu tujuan dari studi ini akan mencoba melihat sejauh mana perkembangan harga pada sektor yang terkait dengan penetapan harga yang diatur pemerintah terhadap perkembangan harga di sektor lain. Dengan demikian, ketika menganalisis pengendalian inflasi daerah tentu saja tidak dapat menitikberatkan pada komoditas tertentu yang dianggap penyumbang terbesar inflasi daerah, namun perlu dilakukan pengendalian harga secara simultan terhadap sektor lain. Shock harga yang terjadi pada suatu komoditas bisa diakibatkan oleh shock yang terjadi pada komoditas lainnya.

\section{I.2. Karakteristik Inflasi di Sumatera Barat}

Perhitungan inflasi secara nasional merupakan hasil dari kompilasi perhitungan inflasi seluruh daerah yang telah dilakukan pembobotan. Propinsi Sumatera Barat sendiri inflasinya diwakili oleh Kota Padang di mana mendapatkan pembobotan sebesar 1,69 persen terhadap inflasi nasional dengan menggunakan SBH 2007. Bobot ini angkanya lebih kecil dibandingkan bobot dengan menggunakan SBH 2002 yaitu sebesar 2,07 persen.

8 Majardi (2002) memberi catatan bahwa pengetahuan tentang perkiraan kecenderungan pergerakan harga BBM menjadi sangat penting dalam mengetahui pergerakan harga administered pada khususnya. Penetapan harga BBM yang mendekati market base akan mengakibatkan perkiraan mengenai pergerakan harga BBM serta pengaruhnya terhadap perkembangan harga barang secara umum menjadi lebih sulit untuk diukur. Lihat selengkapnya pada Fadjar Madjardi, "Administered Price dan Pola Penetapan Harga BBM," Catatan Riset, Direktorat Kebijakan Moneter, Bank Indonesia, Juli 2002. 


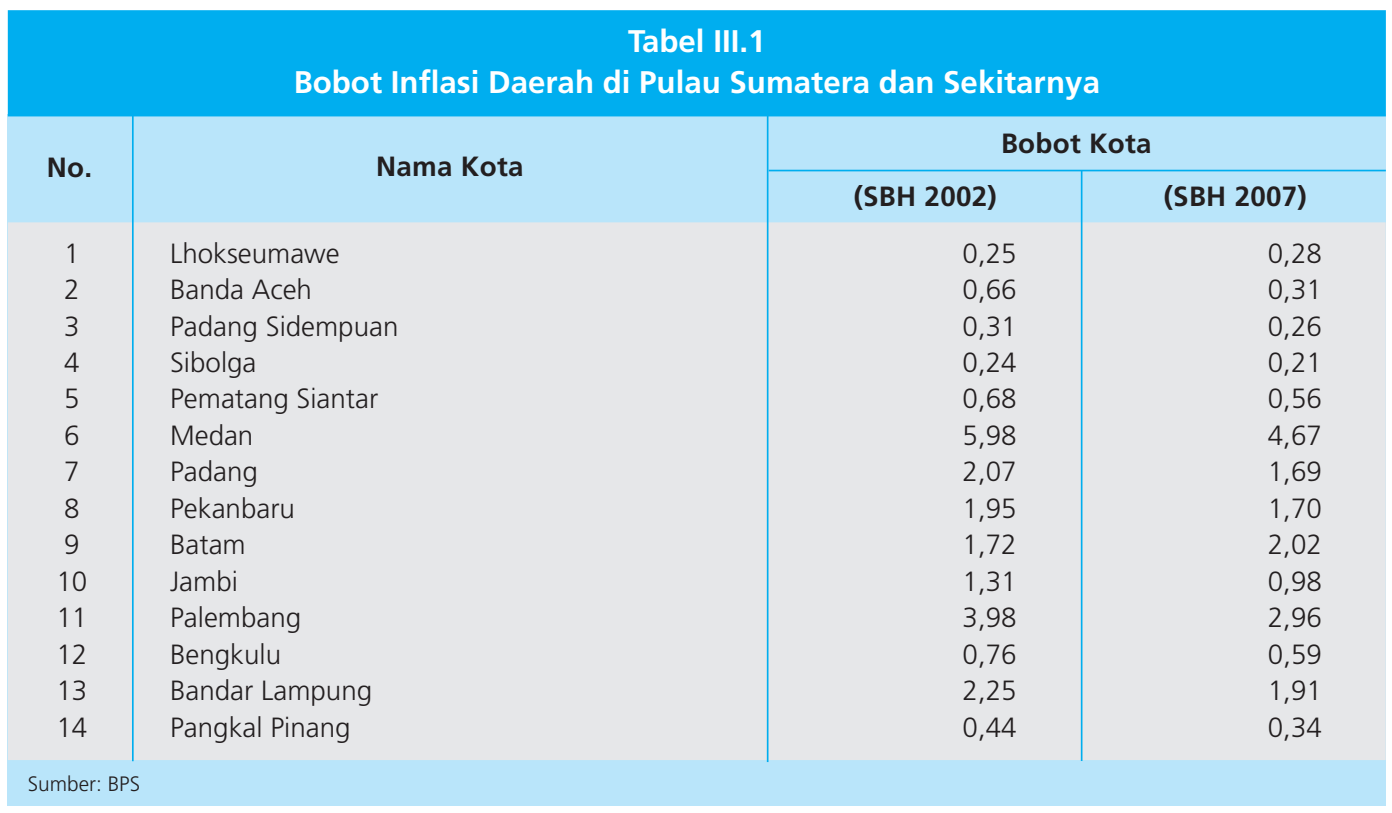

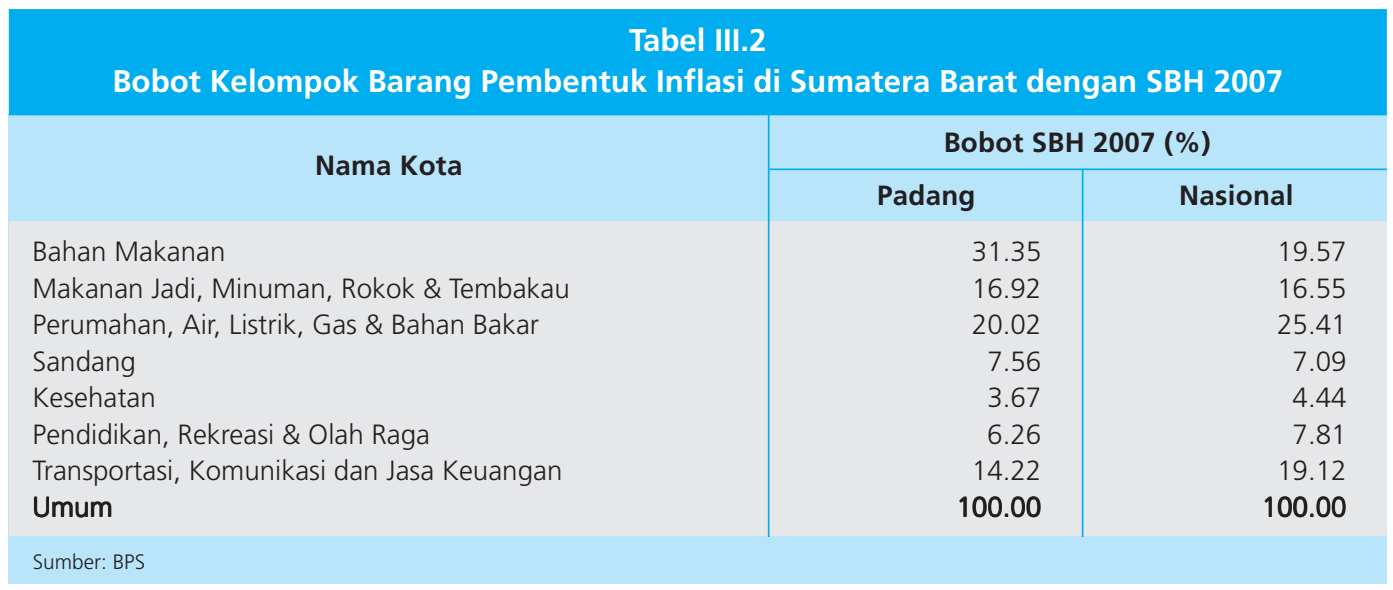

Dibandingkan dengan daerah-daerah lain di Pulau Sumatera dan sekitarnya, dengan SBH 2007 bobot inflasi Kota Padang lebih kecil dibandingkan dengan Medan (4,67\%), Palembang (2,96\%), Batam (2,02\%), Bandar Lampung (1,91\%), dan Pekanbaru (1,70\%). Dengan demikian, bobot inflasi Kota Padang terhadap nasional berada sedikit di atas rata-rata bobot inflasi daerah-daerah di Pulau Sumatera dan sekitranya yang rata-rata sebesar 1,32\% . (Lihat Tabel III.1)

Inflasi di Sumatera Barat (yoy) periode 2007-2008 (Grafik III.1.), secara trend angkanya lebih tinggi dibandingkan dengan inflasi nasional. Pada triwulan IV tahun 2008 angka inflasi 
Sumatera Barat sebesar 12,68\%, lebih tinggi dibandingkan inflasi nasional sebesar 11,06\%. Dari tahun 2006 hingga 2008, hanya pada kuartal tertentu saja angka inflasi Sumatera Barat (уоу) lebih rendah dibandingkan inflasi nasional. Pergerakan inflasi Sumbar cenderung mengikuti pergerakan inflasi nasional, namun sejak kenaikan harga BBM di bulan Mei 2008 inflasi Sumbar secara persisten selalu berada di atas inflasi nasional. Namun dengan bobot yang diberikan pada SBH 2007 hanya sebesar 1,69\%, maka tekanan pada besaran nilai inflasi Sumatera Barat terhadap inflasi nasional menjadi tidak begitu besar. Pembobotan tersebut terkait juga dengan scope ekonomi Sumatera Barat yang tidak begitu besar terhadap perekonomian nasional secara keseluruhan.

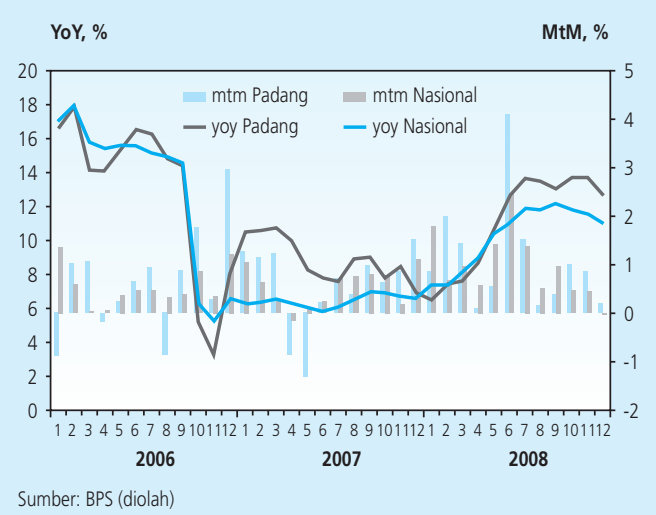

Grafik III.1

Inflasi Nasional dan-Sumatera Barat (y-o-y)

Berdasarkan kelompok komoditas pembentuk inflasi di Sumatera Barat dengan menggunakan SBH 2007, bobot yang diberikan paling besar pada kelompok bahan makanan yaitu 31,35\%. (lihat Tabel III.2). Hal ini didasari oleh keranjang konsumsi masyarakat (basket of goods) di mana masyarakat dalam pemenuhannya banyak berasal dari kelompok bahan makanan. Kelompok bahan makanan ini secara umum memiliki kecenderungan sifatnya yang inelastis terhadap pendapatan, terutama pada pemenuhan makanan kebutuhan pokok. ${ }^{9}$ Kelompok bahan makanan juga rentan fluktuasi harganya akibat kondisi seperti permasalahan cuaca, sifatnya yang musiman, dan pemenuhan pasokan untuk memenuhi kebuthan yang ada. Pada kondisi di daerah, pengendalian harga pada kelompok komoditas ini menjadi perhatian

9 Inelastis di sini yaitu tingkat elastisitas pendapatan terhadap kuantitas barang lebih rendah dari 1. Artinya, ketika pendapatan masyarakat turun sebesar 1\%, pengurangan konsumsi dalam kuantitas komoditas tersebut kurang dari 1\%. Dalam hal ini perlu dilakukan analisis lebih lanjut mengenai kondisi di Sumatera Barat pada konteks komoditas pada kelompok bahan makanan tersebut. 
penting, terutama seringkali menjadi penyumbang inflasi terbesar di daerah. Pada tahun 2008, inflasi kelompok bahan makanan secara tahunan (yoy) sebesar 21,26\%, merupakan inflasi terbesar dibandingkan kelompok komoditas lainnya. (Tabel III.3).

Bobot terbesar kedua pembentuk inflasi di Sumatera Barat adalah kelompok perumahan, air, listrik, gas, dan bahan bakar yaitu sebesar 20,02\%. Kelompok komoditas ini sangat rentan dengan pola penetapan harga melalui kebijakan pemerintah (administered prices), terutama pada bahan bakar. Pola pergerakan pada kelompok barang ini rentan terhadap shock yang cukup besar terkait dengan kebijakan penetapan harga oleh pemerintah.

\begin{tabular}{|c|c|c|}
\hline \multicolumn{3}{|c|}{$\begin{array}{c}\text { Tabel III.3 } \\
\text { Inflasi tahun } 2008 \text { pada Masing-Masing Kelompok dan Sub-Kelompok Komoditas } \\
\text { Pembentuk Inflasi Umum di Sumatera Barat }\end{array}$} \\
\hline \multirow{2}{*}{ Komoditas } & \multicolumn{2}{|c|}{ Inflasi Des 2008} \\
\hline & $(\mathrm{mtm})$ & (уоу) \\
\hline UMUM & 0,21 & 12,68 \\
\hline BAHAN MAKANAN & 0,55 & 21,26 \\
\hline Padi-padian, Umbi-umbian dan Hasilnya & $-0,22$ & 16,84 \\
\hline Daging dan Hasil-hasilnya & $-1,05$ & 18,29 \\
\hline Ikan Segar & $-2,60$ & 26,49 \\
\hline Ikan Diawetkan & 1,62 & 41,79 \\
\hline Telur, Susu dan Hasil-hasilnya & $-2,00$ & 17,62 \\
\hline Sayur - sayuran & $-3,25$ & 23,59 \\
\hline Kacang - kacangan & 0,03 & 11,73 \\
\hline Buah - buahan & 4,80 & 35,62 \\
\hline Bumbu - bumbuan & 12,28 & 16,46 \\
\hline Lemak dan Minyak & $-1,06$ & 25,49 \\
\hline Bahan Makanan Lainnya & 0,12 & 5,70 \\
\hline MAKANAN JADI, MINUMAN, ROKOK \& TEMBAKAU & 0,82 & 13,73 \\
\hline Makanan Jadi & 1,26 & 17,97 \\
\hline Minuman yang Tidak Beralkohol & 0,37 & 7,32 \\
\hline Tembakau dan Minuman Beralkohol & 0,00 & 7,80 \\
\hline PERUMAHAN, AIR, LISTRIK, GAS \& BAHAN BAKAR & 0,10 & 8,01 \\
\hline Biaya Tempat Tinggal & 0,14 & 7,44 \\
\hline Bahan Bakar, Penerangan dan Air & $-0,34$ & 7,90 \\
\hline Perlengkapan Rumahtangga & 1,83 & 17,15 \\
\hline Penyelenggaraan Rumahtangga & 0,03 & 5,30 \\
\hline SANDANG & 0,98 & 5,69 \\
\hline Sandang Laki-laki & $-0,18$ & 2,27 \\
\hline Sandang Wanita & 0,00 & 6,27 \\
\hline Sandang Anak-anak & $-0,03$ & 5,94 \\
\hline Barang Pribadi dan Sandang Lain & 4,95 & 9,25 \\
\hline KESEHATAN & 0,08 & 4,87 \\
\hline Jasa Kesehatan & 0,00 & 1,42 \\
\hline Obat-obatan & 0,00 & 5,52 \\
\hline
\end{tabular}




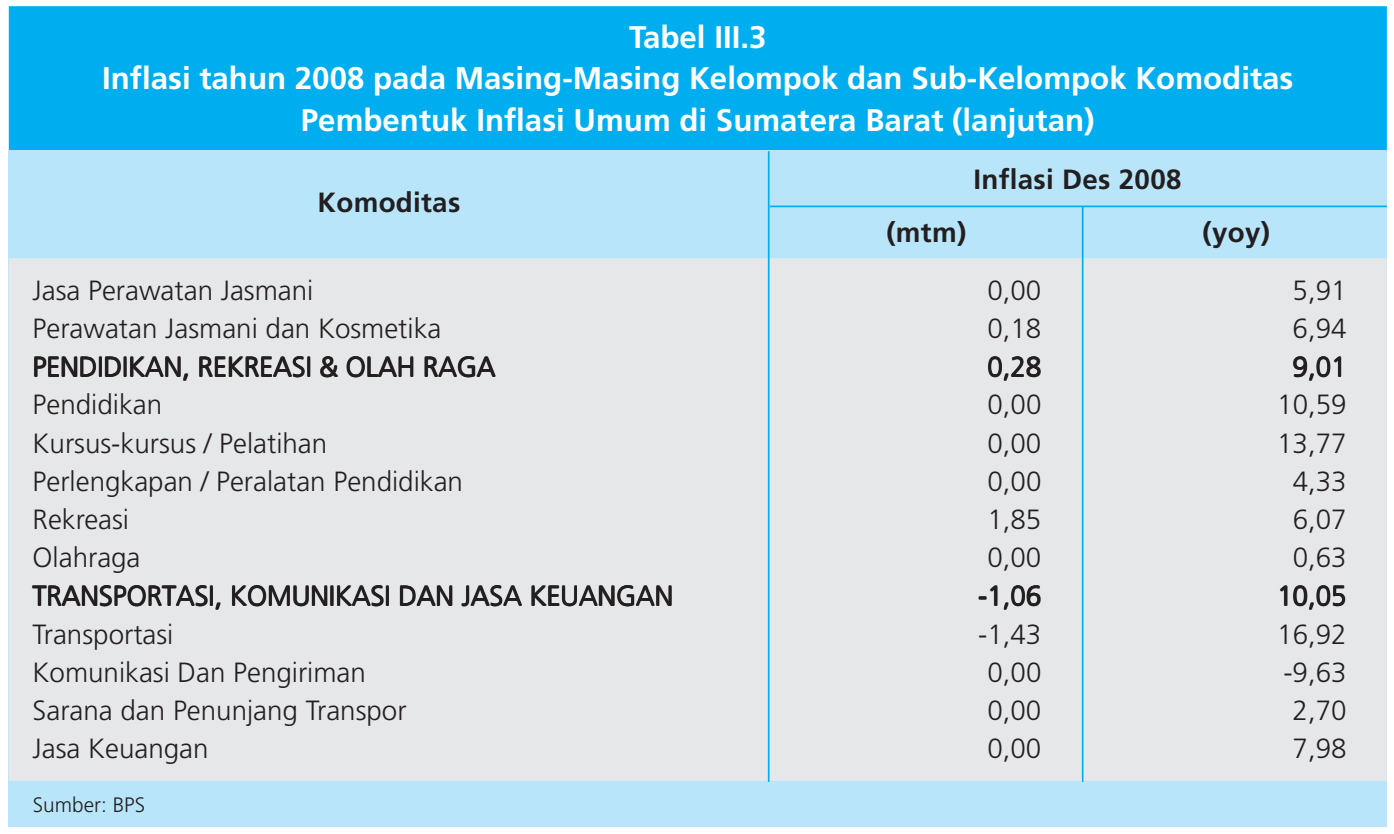

Kemudian bobot terbesar selanjutnya adalah kelompok makanan jadi, minuman, rokok, dan tembakau, 16,92\%, dan kelompok transportasi, komunikasi, dan jasa keuangan, 14,22\%. Kedua kelompok komoditas ini tentu pergerakan harganya tidak dapat dipisahkan dengan dua kelompok komoditas selanjutnya. Pada kelompok makanan jadi, tentu biaya inputnya bergantung pada harga di kelompok bahan makanan dan kelompok perumahan, air, listrik,

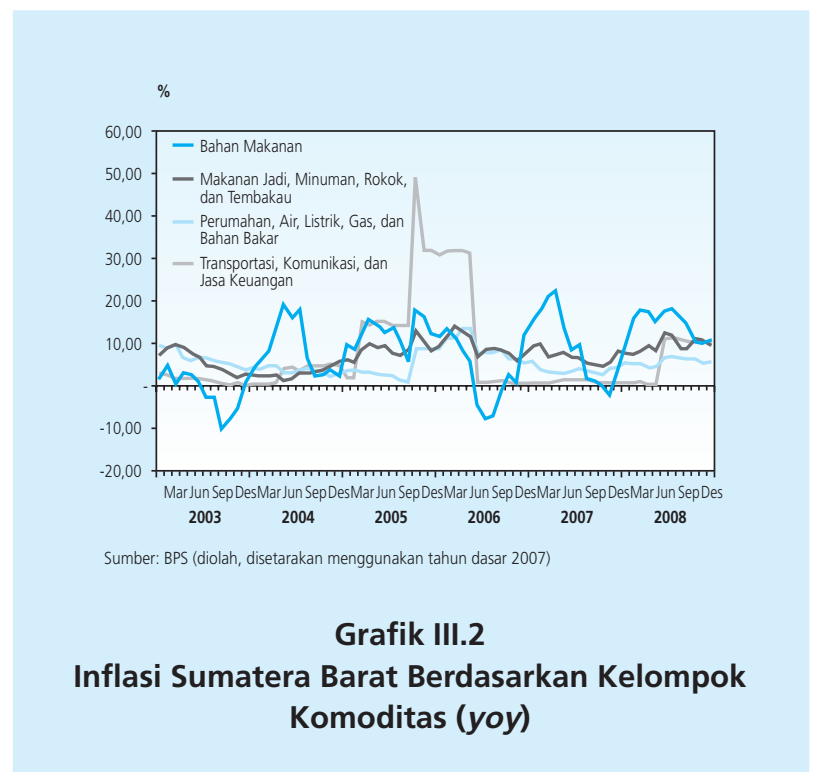


dan gas. Begitupula pada kelompok transportasi, yang sangat terkait dengan sub kelompok bahan bakar, di mana secara bulanan inflasi di Sumatera Barat pada bulan Desember 2008 pada kelompok bahan bakar, penerangan, dan air mengalami deflasi sebesar 0,34\%, diikuti pula deflasi pada sub kelompok transportasi sebesar 1,34\%. (Tabel III.3).

Berdasarkan Grafik III.2., inflasi pada kelompok bahan makanan; kelompok makanan jadi, minuman, rokok, dan tembakau; kelompok transportasi, komunikasi, dan jasa keuangan; dan kelompok perumahan, air, listrik, dan bahan bakar pergerakannya sering bergejolak, atau seringkali berada pada tingkat inflasi (yoy) di atas 10\%. Pada kelompok bahan makanan, pergerakan inflasinya sangat bergejolak mengikuti sifatnya yang dipengaruhi oleh pola musiman, di mana pada awal pertengahan tahun inflasinya cukup tinggi, kemudian setelah itu mengalami penurunan pada pertengahan tahun, dan kembali meningkat menjelang akhir tahun. Namun, apabila terjadi shock, seperti kenaikan harga yang cukup besar pada bulan Oktober 2005 terkait dengan peningkatan harga BBM oleh pemerintah yang total mencapai 120-an persen, begitupula pada bulan Mei 2008, namun shock-nya tidak sebesar Oktober 2005, pola pergerakan harganya menjadi berubah. Pada pertengahan tahun pergerakan harga kelompok bahan makanan cenderung mengalami penurunan inflasi, namun akibat shock tersebut penurunannya menjadi tertahan, yaitu tetap mengalami inflasi lebih lanjut. Pergerakan harga di kelompok ini juga rentan dipengaruhi oleh ketersediaan pasokan akibat distribusi yang tidak lancar, serta kendala infrastruktur yang mengakibatkan transportasi pendistribusian pemenuhan kelompok bahan makanan ini menjadi tersendat.

Pergerakan inflasi pada kelompok makanan jadi, minuman rokok, dan tembakau hampir menyerupai pada peregerakan di kelompok perumahan, air, listrik, gas, dan bahan bakar. Kedua kelompok ini juga terlihat mengalami dampak dari shock kenaikan bahan bakar baik pada bulan Oktober 2005 maupun pada Mei 2008. Kedua kelompok tersebut merespon dengan juga mengalami peningkatan ketika pada kelompok transportasi, komunikasi, dan jasa keuangan mengalami shock yang signifikan. Hal tersebut menunjukkan bahwa kenaikan harga bahan bakar menstimulus terjadinya peningkatan harga pula pada kelompok komoditas lainnya.

Pada kelompok perumahan, listrik, air, gas dan bahan bakar pergerakannya dapat lebih diredam dalam merespon peningkatan harga pada kelompok lainnya. Berbagai komoditas pada kelompok ini banyak yang harganya ditentukan oleh pemerintah. Dengan demikian, ketika terjadi shock seperti peningkatan harga BBM, pemerintah sedapat mungkin menahan peningkatan di komoditas lainnya. Tentu saja untuk menghindari tekanan yang lebih besar pada daya beli masyarakat, meskipun secara keekonomian biaya inputnya juga turut meningkat. 


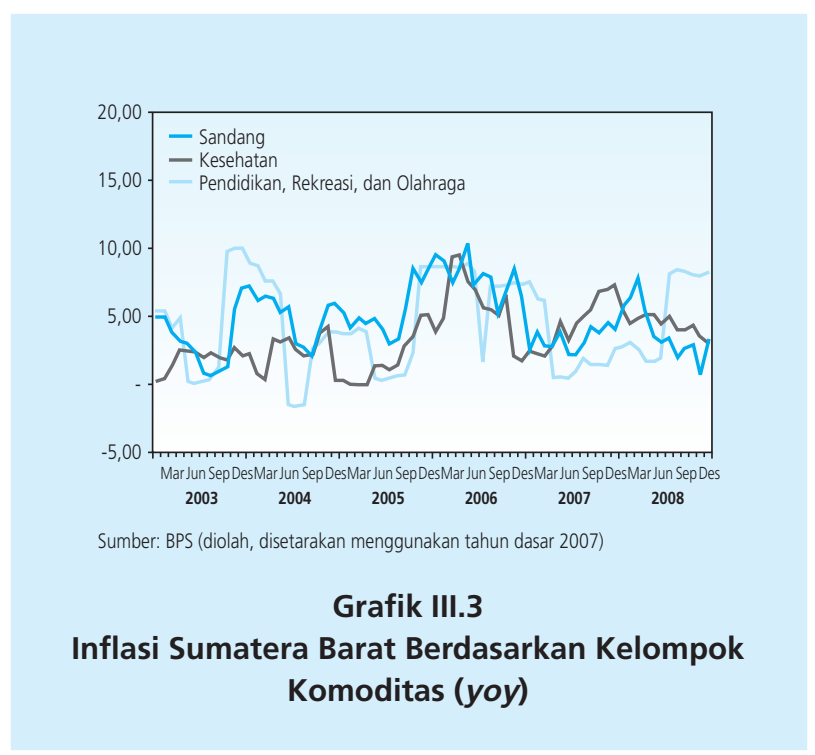

Pada ketiga kelompok komoditas terakhir, yaitu kelompok sandang; kelompok kesehatan; dan kelompok pendidikan, rekreasi, dan olahraga pergerakan inflasi dari ketiga kelompok ini tingkat volatilitasnya tidak terlalu tinggi. Pergerakannya meskipun meningkat namun masih dalam range di sekitar 10 an persen. Walaupun demikian, pergerakan harga ketiga kelompok ini juga terkena dampak shock dari peningkatan harga bahan bakar minyak pada triwulan akhir 2005 yang kemudian berada dalam trend inflasi tinggi sepanjang tahun 2006.

Pada kelompok pendidikan, rekreasi, dan olahraga, pergerakan harganya cenderung meningkat pada setelah pertengahan tahun. Hal ini terkait dengan dimana dibuka dan dimulainya ajaran baru pendidikan banyak berlangsung di pertengahan tahun. Sedangkan pada kelompok kesehatan, pergerakan harganya tidak membentuk pola tertentu, peningkatan fluktuasinya terpengaruh pada shock yang terjadi pada periode tertentu.

Selanjutnya untuk melihat seberapa besar keterkaitan antar harga kelompok komoditas tersebut, dan juga mengetahui bagaimana pergerakannya ke depan jika terjadi shock harga pada suatu kelompok komoditas yang dapat mempengaruhi harga kelompok komoditas lainnya, maka akan digunakan metode ekonometrik untuk melakukan analisis secara lebih lanjut. 


\section{METODOLOGI}

\section{II.1. Teknik Estimasi}

\section{II.1. 1.Pengujian Stationeritas}

Pengujian ini menggunakan uji stasioneritas dengan menggunakan Augmented DickeyFuller Test for Unit Roots untuk mengetahui bentuk stasioneritas ${ }^{10}$ dan derajat integrasi dari variabel-variabel yang digunakan.

Berdasarkan teori dasar mengenai unit root, diasumsikan persamaan mengikuti proses $A R(1)$, yaitu:

$$
y_{t}=\rho y_{t-1}+x_{t}^{\prime} \delta+\varepsilon_{t}
$$

Di mana:

$x_{t} \quad=$ Optional exogenous regressor yang bisa bersifat konstan atau konstan dan trend. $\rho$ dan $\delta=$ Parameter-parameter yang akan diestimasi

$\varepsilon_{t} \quad=$ White noise

Jika $|\rho| \geq 1, y$ adalah seri non-stasioner, dan varians dari $y$ akan terus meningkat seiring waktu secara tidak terbatas. Jika $|\rho| \leq 1, y$ adalah seri stasioner. Dengan demikian, hipotesis mengenai terjadinya stasioneritas dapat diuji melalui estimasi nilai $\rho$.

$$
\begin{aligned}
& \mathrm{H}_{0}: \rho=1 \\
& \mathrm{H}_{1}: \rho<1
\end{aligned}
$$

Melalui Augmented Dickey-Fuller Test, diestimasi dengan mengurangi kedua sisi pada persamaan (1) dengan $y_{t-1}$ maka persamaan menjadi:

$$
\Delta y_{t}=a y_{t-1}+x_{t}^{\prime} \delta+\varepsilon_{t}
$$

Di mana: $a=\rho-1$, maka hipotesis yang digunakan menjadi:

$$
\begin{aligned}
& \mathrm{H}_{0}: a=0 \\
& \mathrm{H}_{1}: a<0
\end{aligned}
$$

Dan menggunakan konvensional $t$-ratio untuk $\boldsymbol{a}$ :

$$
t_{a}=\frac{\hat{a}}{(\operatorname{se}(\hat{a}))}
$$

Di mana $\hat{a}$ adalah nilai estimasi untuk $a$, dan se $(\hat{a})$ adalah standar error. 
Asumsi yang digunakan dalam pengujian seperti intercept dan trend bergantung pada pergerakan seri data yang ada. Jika data memiliki gelombang yang cenderung tidak sama, maka digunakan asumsi intercept. Data dianggap stasioner jika hasil test menunjukkan penolakan pada hipotesis nol dengan nilai $p$-value lebih kecil dari $\alpha$ yang digunakan.

\section{II.1.2. Pengujian Kointegrasi}

Pengujian kali ini menggunakan Johansen Cointegration Test. Menurut Engle dan Granger (1987), suatu kombinasi linier antara dua atau lebih seri data non-stasioner akan menghasilkan integrasi yang stasioner. Kombinasi linier stasioner dapat juga dikatakan sebagai persamaan yang terkointegrasi (cointegrating equation), dan dapat diinterpretasikan sebagai hubungan keseimbangan jangka panjang di antara variabel-variabel yang ada.

Jadi, tujuan dari cointegration test sangat jelas, yaitu untuk menentukan apakah kelompok seri data yang non-stasioner terkointegrasi apa tidak. Bentuk hubungan dalam kointegrasi sendiri menggunakan bentuk dasar dari spesifikasi Vector Error Correcting (VEC) dengan berbasiskan implementasi dari Vector Auto Regression (VAR) dengan menggunakan metodologi yang dikembangkan oleh Johansen (1991). Dituliskan persamaan VAR dengan orde $p$, yaitu:

$$
y_{t}=A_{1} y_{t-1}+\ldots+A_{p} y_{t-p}+B x_{t}+\varepsilon_{t}
$$

Di mana $y_{t}$ adalah vektor $k$ dari non-stasioner variabel $I(1), x_{t}$ adalah vektor $d$ dari variabel determinan, dan $\varepsilon_{t}$ adalah vektor error. Dapat dituliskan kembali persamaan VAR di atas menjadi:

$$
\Delta y_{t}=\Pi y_{t-1}+\sum_{t=1}^{p-1} \Gamma_{t} \Delta y_{t-1}+B x_{t}+\varepsilon_{t}
$$

Di mana:

$$
\begin{gathered}
\Pi=\sum_{t=1}^{p} A_{t}-I \\
\Gamma_{t}=-\sum_{j=i+1}^{p} A_{j}
\end{gathered}
$$

Metode yang dikembangkan Johansen mengestimasi matriks $\Pi$ dari unrestricted VAR, dan menguji apakah dapat menolak restriksi yang ada dengan mengurangi rank dari $\Pi$. 


\section{II.1.3. Model Vector Autoregression (VAR) dan Vector Error Correction Model (VECM)}

Seperti pada arah studi ini untuk mengetahui bagaimana keterkaitan harga pada kelompok komoditas pembentuk inflasi, maka studi ini akan dikonstruksi menggunakan model Vector Autoregression (VAR). Model ini menganggap semua variabel dalam model tersebut adalah endogen, kemudian diestimasi secara bersama-sama dan simultan (Gujarati, 2004). ${ }^{11}$ Model VAR atau unrestricted VAR ini juga menggunakan kerangka logis dengan tidak menggunakan secara eksplisit persamaan struktural dengan spesifikasi berdasarkan teori ekonomi yang ada (Johnston dan DiNardo, 1997). ${ }^{12}$

Estimasi model VAR memasukkan variabel endogen yang dipengaruhi oleh variabel dirinya sendiri pada periode sebelumnya (lagged atau past value), dan juga pengaruh variabel-variabel endogen lainnya dalam model. Selain itu, sebelum melakukan estimasi tersebut, harus dipastikan juga bahwa persamaan-persamaan yang ada dalam sistem teridentifikasi baik exactly-identified atau over-identified.

Adapun persamaan-persamaan dalam sistem pada model VAR ini adalah sebagai berikut:

$$
\begin{aligned}
& B A M A_{t}=\alpha_{1}+\sum_{i=1}^{k} \beta_{j} B A M A_{t-i}+\sum_{i=1}^{k} \gamma_{i} M A J A D I_{t-i}+\sum_{i=1}^{k} \vartheta_{i} P_{E R U M_{t-i}}+\sum_{i=1}^{k} \theta_{i} S A N D_{t-i}+ \\
& \sum_{i=1}^{k} \delta_{j} K E S_{t-i}+\sum_{i=1}^{k} \phi_{i} P E N D I D I_{t-i}+\sum_{j=1}^{k} \psi_{j} \operatorname{TRANS}_{t-i}+u_{1 t} \\
& M A J A D I_{t}=\alpha_{2}+\sum_{i=1}^{k} \beta_{i} B A M A_{t-i}+\sum_{i=1}^{k} \gamma_{j} M A J A D I_{t-i}+\sum_{i=1}^{k} \vartheta_{i} P_{E R U M_{t-i}}+\sum_{i=1}^{k} \theta_{i} S A N D_{t-i}+ \\
& \sum_{i=1}^{k} \delta_{j} K E S_{t-i}+\sum_{i=1}^{k} \phi_{i} P E N D I D I_{t-i}+\sum_{i=1}^{k} \psi_{i} \operatorname{TRANS}_{t-i}+u_{2 t} \\
& \operatorname{PERUM}_{t}=\alpha_{1}+\sum_{i=1}^{k} \beta_{i} \text { BAMA }_{t-i}+\sum_{i=1}^{k} \gamma_{i} M_{A} A J A D I_{t-i}+\sum_{i=1}^{k} \vartheta_{i} P E R U M_{t-i}+\sum_{i=1}^{k} \theta_{i} S A N D_{t-i}+ \\
& \sum_{i=1}^{k} \delta_{i} K E S_{t-i}+\sum_{i=1}^{k} \phi_{i} P E N D I D I_{t-i}+\sum_{i=1}^{k} \psi_{i} \operatorname{TRANS}_{t-i}+u_{3 t} \\
& S A N D_{t}=\alpha_{1}+\sum_{i=1}^{k} \beta_{i} B_{A M A_{t-i}}+\sum_{i=1}^{k} \gamma_{i} M A J A D I_{t-i}+\sum_{i=1}^{k} \vartheta_{i} P E R U M_{t-i}+ \\
& \sum_{i=1}^{k} \theta_{j} S A N D_{t-i}+\sum_{i=1}^{k} \delta_{i} K E S_{t-i}+\sum_{i=1}^{k} \phi_{i} \operatorname{PENDIDI}_{t-i}+\sum_{i=1}^{k} \psi_{i} \operatorname{TRANS}_{t-i}+u_{4 t}
\end{aligned}
$$

11 Berdasarkan Sims (1980), metode ini dilakukan secara simultan pada suatu sekelonpok variabel dengan tanpa menentukan secara a priori pemisahan mana variabel endogen dan eksogen. Lihat selengkapnya dalam Christopher A. Sims, "Macroeconomic and Reality," Econometrica, Vol. 48, 1980, hlm. 1-48.

12 Lihat selengkapnya dalam Jack Johnston, dan John DiNardo, Econometric Methods, 4th ed. (New York : McGraw-Hill Companies, 1997), hlm. 297. 


$$
\begin{aligned}
& K E S_{t}=\alpha_{1}+\sum_{i=1}^{k} \beta_{i} \text { BAMA }_{t-i}+\sum_{i=1}^{k} \gamma_{i} \text { MAJADI }_{t-i}+\sum_{i=1}^{k} \vartheta_{i} \text { PERUM }_{t-i}+\sum_{i=1}^{k} \theta_{i} S_{A N D_{t-i}}+ \\
& \sum_{i=1}^{k} \delta_{i} K_{E S}+\sum_{i=1}^{k} \phi_{i} \text { PENDIDI }_{t-i}+\sum_{i=1}^{k} \psi_{i} \operatorname{TRANS}_{t-i}+u_{5 t} \\
& \text { PENDIDI }_{t}=\alpha_{1}+\sum_{i=1}^{k} \beta_{i} \text { BAMA }_{t-i}+\sum_{i=1}^{k} \gamma_{i} \text { MAJADI }_{t-i}+\sum_{i=1}^{k} \vartheta_{i} \text { PERUM }_{t-i}+\sum_{i=1}^{k} \theta_{i} S_{A N D_{t-i}}+ \\
& \sum_{i=1}^{k} \delta_{i} K E S_{t-i}+\sum_{i=1}^{k} \phi_{i} P E N D I D I_{t-i}+\sum_{i=1}^{k} \psi_{i} \operatorname{TRANS}_{t-i}+u_{6 t} \\
& \operatorname{TRANS}_{t}=\alpha_{1}+\sum_{i=1}^{k} \beta_{i} \text { BAMA }_{t-i}+\sum_{i=1}^{k} \gamma_{i} \text { MAJADI }_{t-i}+\sum_{i=1}^{k} \vartheta_{i} \text { PERUM }_{t-i}+\sum_{i=1}^{k} \theta_{i} \operatorname{SAND}_{t-i}+ \\
& \sum_{i=1}^{k} \delta_{i} K E S_{t-i}+\sum_{i=1}^{k} \phi_{i} \text { PENDIDI }_{t-i}+\sum_{i=1}^{k} \psi_{i} \operatorname{TRANS}_{t-i}+u_{7 t}
\end{aligned}
$$

Di mana:

$B A M A_{t}=$ indeks harga kelompok bahan makanan

$M A J A D I_{t}=$ indeks harga kelompok makanan jadi, minuman, rokok, dan tembakau

$\operatorname{PERUM}_{t}=$ indeks harga kelompok perumahan, air, listrik, gas, dan bahan bakar

$S A N D_{t} \quad=$ indeks harga kelompok sandang

$K E S_{t} \quad=$ indeks harga kelompok kesehatan

$T R A N S_{t}=$ indeks harga kelompok transportasi, komunikasi, dan jasa keuangan

$u_{i t} \quad=$ stochastic error terms atau impulse atau inovasi atau shock dalam VAR

$k \quad=$ lag length

Estimasi akan menggunakan unrestricted VAR jika data-data pada variabel yang ada menunjukkan stasioner pada tingkat level, atau menggunakan VAR in difference jika data nonstasioner namun tidak terintegrasi pada derajat yang sama. Jika data pada semua variabel nonstasioner namun terjadi kointegrasi pada derajat yang sama maka estimasi model menggunakan Vector Error Correction Model (VECM).

Secara umum persamaan-persamaan di atas dapat diringkas ke dalam vektor matriks $\left(Z_{t}\right)$ sebagai berikut:

$$
\mathrm{Z}_{\mathrm{t}}=[B A M A, M A J A D I, \text { PERUM, SAND, KES, PENDIDI, TRANS }]
$$

Jika model VAR dapat ditulis sebagai berikut:

$$
Z_{t}=\sum_{i=1}^{k} \Pi_{i} Z_{t-i}+u_{t}
$$

Maka bentuk first-difference-nya untuk estimasi VECM akan menjadi seperti berikut: 


$$
\Delta Z_{t}=\Pi_{i} Z_{t-i}+\sum_{i=1}^{k-1} \Gamma_{i} \Delta Z_{t-1}+u_{t}
$$

Di mana:

$$
\begin{array}{ll}
\Delta Z_{t}= & \text { matriks vektor first-difference } \\
\Pi \quad=\text { matriks cointegrating vector } \times \text { matriks koefisien } \\
\Gamma_{i} \quad=\text { matriks koefisien } \\
u_{t} \quad=\text { matriks vektor error }
\end{array}
$$

Penentuan selang (lag) optimal dicari dengan menggunakan kriteria informasi yang tersedia. Kandidat selang yang dipilih dapat berdasarkan Likelihood Ratio (LR), Final Prediction Error(FPE), Akaike Information Criterion (AIC), Schwartz Information Criterion(SC), dan HannanQuin Criterion (HQ). ${ }^{13}$ Pemilihan selang optimal juga memperhatikan mana yang menghasilkan Adjusted R-squared terbesar pada variabel-variabel penting dalam sistem.

Selain mengestimasi model VAR, estimasi juga melakukan perhitungan dan analisis pada Impulse Response Function (IRF) untuk melacak respon saat ini dan masa depan pada setiap variabel dengan memanfaatkan informasi seluruh informasi masa lalu semua variabel. Forecast Error Variance Decomposition (FEVD) juga dilakukan untuk memprediksi kontribusi persentase varians setiap variabel terhadap perubahan suatu variabel tertentu.

Perlu ditegaskan bahwa aplikasi model VAR dan VECM ini lebih ditekankan untuk menganalisa kondisi empiris pergerakan harga dan inflasi. Alternatif yang lebih kuat adalah model Structural Vector Autoregressive (SVAR) yang memungkinkan internalisasi teori dalam proses estimasi melalui penetapan restriksi atas hubungan teoritis antar variabel yang terlibat dalam persamaan.

\section{II.2. Data}

Data yang digunakan adalah data bulanan pada kelompok komoditas pembentuk inflasi di Sumatera Barat dari 2002:1 hingga 2008:12. Data tersebut telah disetarakan dengan menggunakan basis SBH 2007 yang diperoleh dari BPS.

13 Jika kriteria informasi hanya merujuk pada sebuah kandidat selang, maka kandidat selang tersebutlah yang paling optimal. 


\begin{tabular}{|c|c|c|c|c|c|c|c|}
\hline \multicolumn{8}{|c|}{$\begin{array}{r}\text { Tabel III.4 } \\
\text { Uraian Statistik Deskriptif Data IH }\end{array}$} \\
\hline & BAMA & MAJADI & PERUM & SAND & KES & PENDIDI & TRANS \\
\hline Mean & 83,47488 & 82,30071 & 86,03119 & 85,29238 & 91,08893 & 88,21702 & 80,65333 \\
\hline Median & 79,625 & 76,855 & 81,155 & 81,87 & 86,94 & 84,38 & 73,89 \\
\hline Maximum & 127,23 & 119,44 & 110,76 & 107,4 & 109,8 & 110,51 & 110,81 \\
\hline Minimum & 58,95 & 60,11 & 62,21 & 67,74 & 78,02 & 70,29 & 54,96 \\
\hline Std, Dev, & 19,57103 & 17,62343 & 13,97014 & 12,90156 & 9,629859 & 11,7672 & 19,36712 \\
\hline Observations & 84 & 84 & 84 & 84 & 84 & 84 & 84 \\
\hline
\end{tabular}

Total observasi untuk estimasi adalah 84 series. Penggunaan kelompok-kelompok komoditas tersebut didasarkan pada pengelompokan komoditas pada SBH 2007. Studi ini jadi lebih mencoba melihat data pada kelompok komoditas tersebut yang sudah diaggregasi dari masing-masing sub-kelompok yang membentuknya.

\begin{tabular}{|c|c|c|c|c|c|c|c|}
\hline & BAMA & MAJADI & PERUM & SAND & KES & PENDIDI & TRANS \\
\hline BAMA & 1,0000 & 0,9818 & 0,9572 & 0,9620 & 0,9702 & 0,9508 & 0,9318 \\
\hline MAJADI & & 1,0000 & 0,9877 & 0,9862 & 0,9925 & 0,9794 & 0,9509 \\
\hline PERUM & & & 1,0000 & 0,9920 & 0,9804 & 0,9906 & 0,9559 \\
\hline SAND & & & & 1,0000 & 0,9794 & 0,9866 & 0,9620 \\
\hline KES & & & & & 1,0000 & 0,9703 & 0,9328 \\
\hline PENDIDI & & & & & & 1,0000 & 0,9493 \\
\hline TRANS & & & & & & & 1,0000 \\
\hline
\end{tabular}

Dari hasil estimasi correlation matrix menunjukkan bahwa antara variabel satu dengan variabel lainnya masing-masing memiliki keterkaitan yang kuat, yaitu nilainya rata-rata di atas 0,8 . Dengan demikian, apabila estimasi menggunakan model VAR dimungkinkan mengingat masing-masing variabel dianggap sebagai variabel endogen yang menerima pengaruh baik dari dirinya sendiri (lag) dan juga variabel lainnya (lag). 


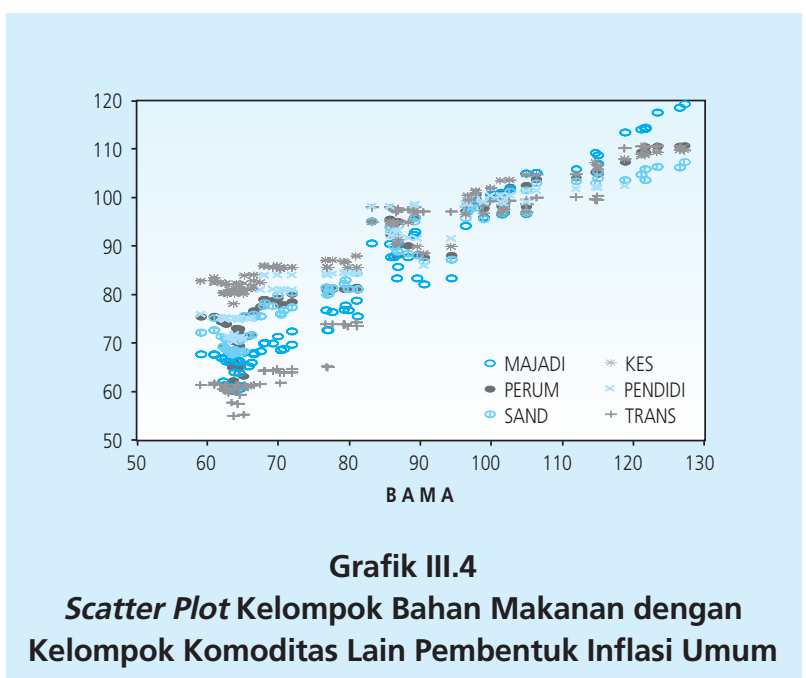

Dari hasil grafis scatter plot di atas dengan mengkaitkan hubungan antara variabel kelompok bahan makanan dengan variabel dari kelompok komoditas lainnya menunjukkan keterkaitan yang kuat, yaitu plot-plot yang ada membentuk trend 45 derajat atau dengan kata lain yaitu memiliki korelasi mendekati 1 .

\section{HASIL DAN ANALISIS}

Hasil pengujian stasioneritas pada semua variabel dengan menggunakan Augmented Dickey-Fuller Test menujukkan bahwa semua variabel stasioner pada tingkat turunan derajat satu (first differences). Setelah melalui pengujian stasioneritas, karena semua variabel menunjukkan stasioner pada derajat yang sama, yaitu derajat satu, maka dilakukan pengujian apakah variabel-variabel tersebut terkointegrasi pada jangka panjang.

Hasil Johansen Cointegration test pada nilai trace test terindikasi terjadi 2 persamaan kointegrasi baik pada $\alpha=5 \%$ maupun $1 \%$. Sedangkan max-eigenvalue test mengindikasikan 2 persamaan kointegrasi pada $\alpha=5 \%$, juga mengindikasikan adanya 1 persamaan kointegrasi pada $\alpha=1 \%$. Hal ini juga konsisten dengan pengujian melalui Engle-Granger di mana residual hasil estimasi persamaan variabel-variabel tersebut adalah stasioner. Apabila menggunakan lag yang sama dengan penggunaan lag optimal pada system VAR, yaitu lag 7, hasil pengujian juga menunjukkan hasil kointegrasi, di mana trace test mengindikasikan adanya 6 persamaan kointegrasi pada $\alpha=5 \%$ dan 1\%. Max-eigenvalue test juga mengindikasikan terjadinya 6 persamaan kointegrasi pada $\alpha=5 \%$, dan mengindikasikan terjadi 5 persamaan kointegrasi pada $\alpha=1 \%$. 
Karena hasil pengujian kointegrasi menunjukkan bahwa variabel-variabel tersebut terkointegrasi pada derajat yang sama, yaitu derajat satu (first-difference) maka estimasi model tidak menggunakan VAR namun menggunakan model VECM. Pengujian selang (lag) optimal pada kriteria LR (sequential modified LR test statistic (each test at $5 \%$ level)), FPE (Final Prediction Error), dan AIC (Akaike information criterion) menunjukkan pada lag ke-7, dari hasil estimasi model juga lag ke-7 menghasilkan Adjusted R-squared paling besar.

Hasil Impulse Response Function (IRF) dan Forecast Error Variance Decomposition (FEVD). Impulse response pada VECM ini menggunakan Impulse Response to Generalized One S.D.Innovations. Berikut adalah impulse response variabel masing-masing kelompok komoditas terhadap kelompok komoditas lainnya.

\section{III.1. Kelompok Bahan Makanan (BAMA)}

\section{III.1.1. Impulse Response Function Kelompok Bahan Makanan}

Dari hasil impulse response tersebut menggambarkan bahwa pada bulan pertama ke depan, jika terjadi shock positif sebesar satu standar deviasi (1 S.D.) pada harga kelompok bahan makanan (BAMA) maka akan mengakibatkan peningkatan harga kelompok BAMA itu sendiri sebesar 2,03\%. Namun dampaknya mulai menurun mulai bulan ke-3 hingga kembali pada keseimbangan harga semula diantara bulan ke-10 dan ke-11. Jadi, apabila terjadi shock yang berasal dari kelompok BAMA itu sendiri misalnya akibat dari pengaruh cuaca, musim, atau gagal panen yang mengakibatkan pasokan $B A M A$ tersendat maka akan terjadi peningkatan harga yang penyesuaian menuju ke harga semula cukup membutuhkan waktu yang cukup lama, yaitu sekitar 10-11 bulan.

Apabila terjadi shock positif sebesar 1 S.D. pada kelompok MAJADI berdampak pada peningkatan harga kelompok BAMA pada triwulan pertama rata-rata sebesar 1,16\% kemudian kembali meningkat di akhir triwulan ke-3 pada bulan ke-9 sebesar 1,33\%. Harga kembali mulai menurun mulai bulan ke-10 dan bahkan deflasi -0,09\% di bulan ke-11. Dampak shock pada bulan ke-1 dari kelompok PERUM tidak terlalu besar sekitar 0,86\%, pada kelompok ini termasuk di dalamnya sub-kelompok bahan bakar. Dampak kenaikan bahan bakar terjadi lebih direspon oleh peningkatan harga pada kelompok BAMA dari kelompok TRANS yang didalamnya masuk sub-kelompok transportasi yang menunjang proses distribusi, di mana mengakibatkan peningkatan pada harga kelompok BAMA pada bulan ke-1 sebesar 1,29\%. Namun memasuki bulan ke-4 dan 5 dampak dari kelompok PERUM dan TRANS ini mulai mengalami penurunan. Hasil ini mengkonfirmasi dari analisis dekriptif pada bagian sebelumnya, di mana pergerakan harga kelompok komoditas bahan makanan dipengaruhi 
juga oleh shock yang terjadi pada harga kelompok transportasi, terkait dengan peningkatan harga BBM.

KelompokSAND juga ternyata memiliki dampak terhadap kelompok BAMA dengan menyebabkan peningkatan harga rata-rata sebesar 1,05\% dari bulan ke-1 hingga bulan ke-9, dan menurun pada bulan ke-10 sebesar -0,23\%. Sedangkan shock dari kelompok KES menyebabkan penurunan harga kelompok BAMA di bulan ke-1 sebesar $-0.67 \%$ di mana penurunan ini bertahan hingga bulan ke-5, dan mulai bulan ke- 6 justru menyebabkan peningkatan harga kelompok BAMA.

Dari hasil impulse response menunjukkan bahwa shock yang ada (BAMA, MAJADI, SAND, dan PENDIDI) sebagian besar mulai menurun kembali di bawah harga keseimbangan pada 2-3 bulan terakhir. Hal ini dapat dikatakan bahwa persistensi peningkatan harga pada kelompok BAMA rata-rata berlangsung 1 hingga 10 bulan ke depan.

\section{Response to Generalized One S.D. Innovations}
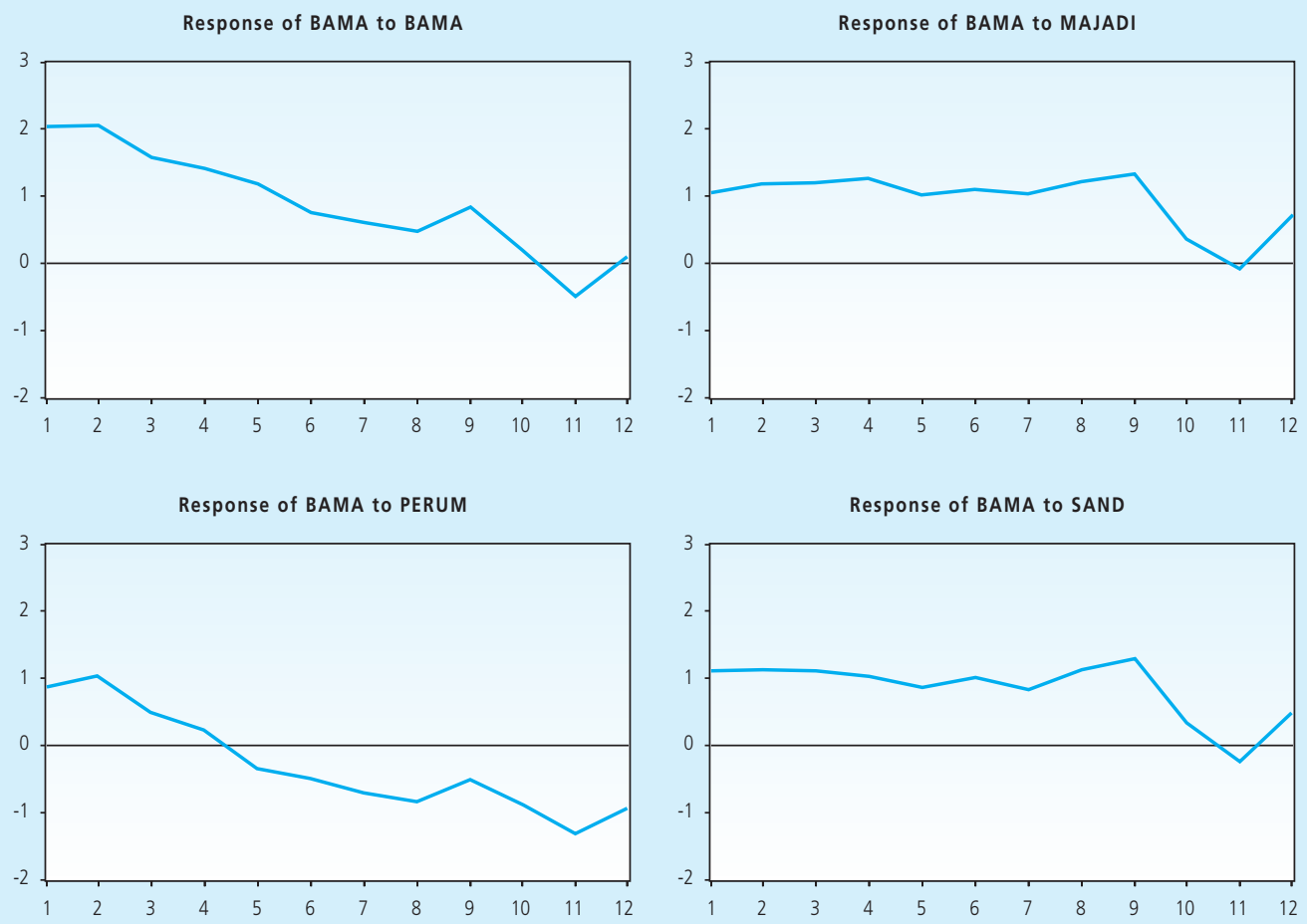

Grafik III.5

Impulse Response Function Kelompok Bahan Makanan 


\section{Response to Generalized One S.D. Innovations}

Response of BAMA to KES

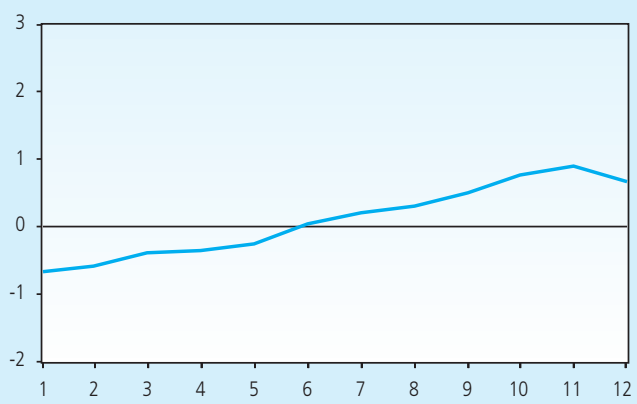

Response of BAMA to TRANS

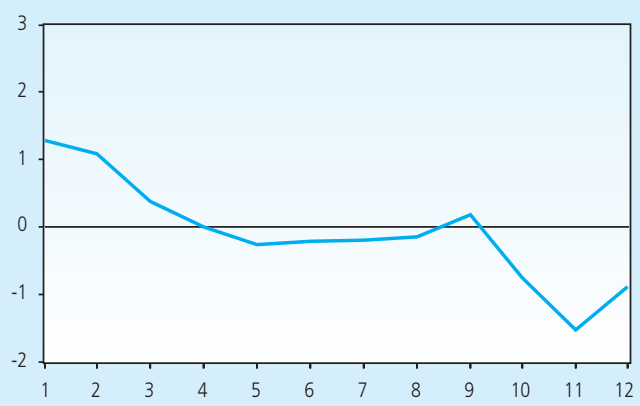

Response of BAMA to PENDIDI

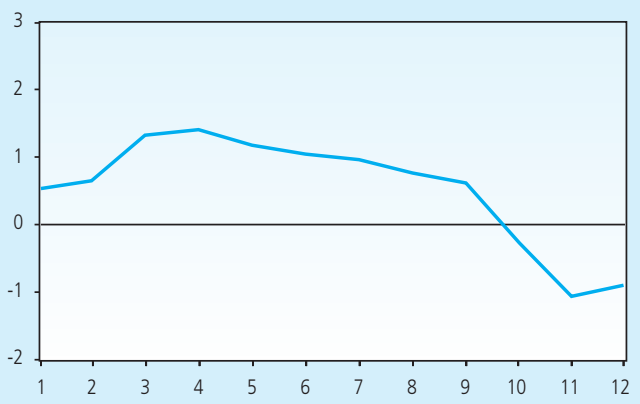

Grafik III.5

Impulse Response Function Kelompok Bahan Makanan (lanjutan)

\section{Tabel III.6}

Impulse Response Function Kelompok Bahan Makanan

\begin{tabular}{c|r|r|r|r|r|r|r|}
\hline Period & BAMA & MAJADI & PERUM & \multicolumn{1}{l|}{ SAND } & \multicolumn{1}{l}{ KES } & PENDIDI & TRANS \\
\hline 1 & 2,0290 & 1,0578 & 0,8601 & 1,1088 & $-0,6657$ & 0,5397 & 1,2884 \\
2 & 2,0470 & 1,1887 & 1,0389 & 1,1175 & $-0,5792$ & 0,6370 & 1,0719 \\
3 & 1,5784 & 1,2049 & 0,4980 & 1,1007 & $-0,4015$ & 1,3274 & 0,3661 \\
4 & 1,4116 & 1,2613 & 0,2318 & 1,0238 & $-0,3689$ & 1,4108 & $-0,0130$ \\
5 & 1,1892 & 1,0170 & $-0,3477$ & 0,8676 & $-0,2569$ & 1,1762 & $-0,2664$ \\
6 & 0,7602 & 1,1029 & $-0,4893$ & 1,0132 & 0,0311 & 1,0376 & $-0,2188$ \\
7 & 0,6163 & 1,0508 & $-0,7097$ & 0,8389 & 0,1955 & 0,9583 & $-0,2077$ \\
8 & 0,4897 & 1,2222 & $-0,8407$ & 1,1174 & 0,3120 & 0,7514 & $-0,1570$ \\
9 & 0,8371 & 1,3287 & $-0,5049$ & 1,2882 & 0,5006 & 0,6194 & 0,1829 \\
10 & 0,2014 & 0,3582 & $-0,8951$ & 0,3480 & 0,7521 & $-0,2682$ & $-0,7693$ \\
11 & $-0,4950$ & $-0,0914$ & $-1,3240$ & $-0,2347$ & 0,8991 & $-1,0699$ & $-1,5326$ \\
12 & 0,1017 & 0,7271 & $-0,9405$ & 0,4883 & 0,6591 & $-0,9064$ & $-0,8867$ \\
& & & & & & &
\end{tabular}




\section{1.2. Variance Decomposition Harga Kelompok Bahan Makanan}

Berdasarkan Tabel III.7 dapat dilihat kontribusi masing-masing shock variabel endogen terhadap fluktuasi harga kelompok BAMA. Data pada bulan pertama menunjukkan kenaikan harga kelompok BAMA lebih disebabkan oleh harga kelompok BAMA itu sendiri (100\%). Jadi faktor yang banyak menyebabkan peningkatan harga pada kelompok BAMA adalah dari dirinya sendiri, hal ini mengkonfirmasi bahwa faktor yang sifatnya struktural dan geografis seperti musim, cuaca, hingga kegagalan panen pada sub-sub kelompok di dalamnya yang banyak terdiri dari hasil produksi di sektor primer seperti pertanian sangat dominan mempengaruhi fluktuasi harganya.

Memasuki akhir triwulan 1 (bulan ke-3)shock fluktuasi harga terbesar kelompok BAMA ini selain dipengaruhi oleh dirinya sendiri $(69,54 \%)$ juga dipengaruhi oleh harga kelompok TRANS (21,30\%), di mana kelompok ini mempunyai peran masuk dalam struktur biaya dalam rangka distribusi pasokan baik dari petani produsen langsung kemudian ke pedagang pengumpul hingga ke pedagang retail. Komposisi kontribusi shock ini masih berlangsung sama hingga akhir triwulan 2 (bulan ke-6) di mana kelompok BAMA sebesar 40,18\%, dan kelompok TRANS sebesar $32,79 \%$.

Pada akhir periode di bulan ke-12 kontribusi shock fluktuasi harga terbesar tersebar pada tiga kelompok yaitu kelompok TRANS, kelompok BAMA itu sendiri, dan kemduian kelompok PERUM, dengan masing-masing konstribusi sebesar 26,09\%, 23,23\%, dan 23,12\%. Kelompok PERUM masuk dalam kontribusi terbesar salah satunya berasal dari sub-kelompok bahan bakar, yang juga bagian dari biaya input dalam transportasi untuk distribusi kelompok BAMA.

\begin{tabular}{|c|c|c|c|c|c|c|c|c|}
\hline & $v$ & ance Dec & npositio & $\begin{array}{l}\text { lbel III } \\
\text { arga }\end{array}$ & 1pok B & Mak & & \\
\hline Period & S.E. & BAMA & MAJADI & PERUM & SAND & KES & PENDIDI & TRANS \\
\hline 1 & 2,0290 & 100,0000 & 0,0000 & 0,0000 & 0,0000 & 0,0000 & 0,0000 & 0,0000 \\
\hline 2 & 3,0085 & 91,7792 & 0,2240 & 0,2417 & 0,1582 & 0,0346 & 0,1560 & 7,4063 \\
\hline 3 & 3,9407 & 69,5369 & 1,4206 & 1,0389 & 0,0979 & 0,1718 & 6,4386 & 21,2953 \\
\hline 4 & 4,9171 & 52,9057 & 2,4799 & 2,5174 & 0,0807 & 0,2551 & 9,7474 & 32,0138 \\
\hline 5 & 5,5787 & 45,6459 & 2,6221 & 6,4668 & 0,0644 & 0,6438 & 10,8128 & 33,7441 \\
\hline 6 & 6,0654 & 40,1848 & 4,0818 & 9,8968 & 0,3337 & 1,1621 & 11,5525 & 32,7883 \\
\hline 7 & 6,4856 & 36,0494 & 5,3073 & 13,8270 & 0,3558 & 2,0736 & 12,2653 & 30,1216 \\
\hline 8 & 6,9312 & 32,0621 & 7,3191 & 17,9293 & 0,7976 & 2,9182 & 11,8451 & 27,1285 \\
\hline 9 & 7,3221 & 30,0372 & 8,5981 & 19,8075 & 1,2007 & 4,5140 & 11,0782 & 24,7644 \\
\hline 10 & 7,6065 & 27,9028 & 8,1191 & 21,1524 & 1,1743 & 6,5131 & 10,3363 & 24,8020 \\
\hline 11 & 8,0098 & 25,5455 & 7,3815 & 22,0953 & 1,0607 & 7,8876 & 10,3521 & 25,6773 \\
\hline 12 & 8,4030 & 23,2255 & 7,5906 & 23,1151 & 0,9806 & 8,5982 & 10,4004 & 26,0897 \\
\hline
\end{tabular}




\section{III.2. Kelompok Makanan Jadi, Minuman, Rokok, dan Tembakau (MAJADI)}

\section{III.2.1. Impulse Response Function Kelompok Makanan Jadi, Minuman, Rokok, dan Tembakau}

Hasil IRF pada kelompok MAJAD/memperlihatkan bahwa jika terjadi shock positif sebesar 1 S.D. pada harga kelompok BAMA menyebabkan peningkatan harga pada kelompok MAJADI sebesar 0,42\%, begitu pula dari shock dirinya sendiri yang menyebabkan peningkatan sebesar $0,81 \%$. Pengaruh shock dari kelompok BAMA hingga bulan ke-7 menyebabkan fluktuasi peningkatan harga pada kelompok MAJADI dan kemudian pada bulan ke-8 dan 9 mengalami penurunan dan kembali mulai mendekati harga semula dengan peningkatan harga yang lebih kecil di akhir periode tahunan $(0,06 \%)$.

Shock harga yang terjadi pada kelompok PERUM dan TRANS sebesar 1 S.D. pada bulan pertama menyebabkan peningkatan harga pada kelompok MAJAD/sebesar 0,40\% dan 0,57\%. Kedua kelompok ini banyak yang masuk sebagai input pada produksi kelompok MAJAD/selain dari bahan baku yang banyak berasal dari kelompok BAMA. Kelompok TRANS terus memberikan dampak peningkatan harga pada kelompok MAJADI hingga bulan ke-7 (0,15\%) dan kemudian setelah itu memberikan pengaruh penurunan harga hingga akhir tahun (bulan ke-12) sebesar $-0,07 \%$. Begitupula pada kelompok PERUM yang banyak diisi oleh sub-kelompok kebutuhan energi dan bahan bakar, memberikan pengaruh peningkatan harga kelompok MAJAD/ hingga bulan ke-8, dan setelah itu memberikan dampak penurunan hingga akhir tahun sebesar $0,20 \%$. Hasil ini juga sesuai dengan analisis sebelumnya, di mana pergerakan harga kelompok makanan jadi, minuman, rokok, dan tembakau, selain tidak terlepas dari harga bahan makanan sebagai bagian inputnya, juga dipengaruhi oleh shock yang terjadi pada kelompok transportasi, komunikasi dan jasa keuangan.

Temuan menarik dari hasil ini, shock harga kelompok SAND memberikan pengaruh yang persisten di mana hingga akhir tahun rata-rata memberikan pengaruh peningkatan harga pada kelompok MAJADI sebesar 0,51\%. Selain itu, shock yang terjadi pada MAJADI, SAND, dan KES cenderung mengakibatkan peningkatan harga pada kelompok MAJAD/secara lebih persisten, dibandingkan dampak shock dari kelompok BAMA, PERUM, PENDIDI, dan TRANS, yang mulai turun pada bulan ke-7 dan 8 . 
Response to Generalized One S.D. Innovations
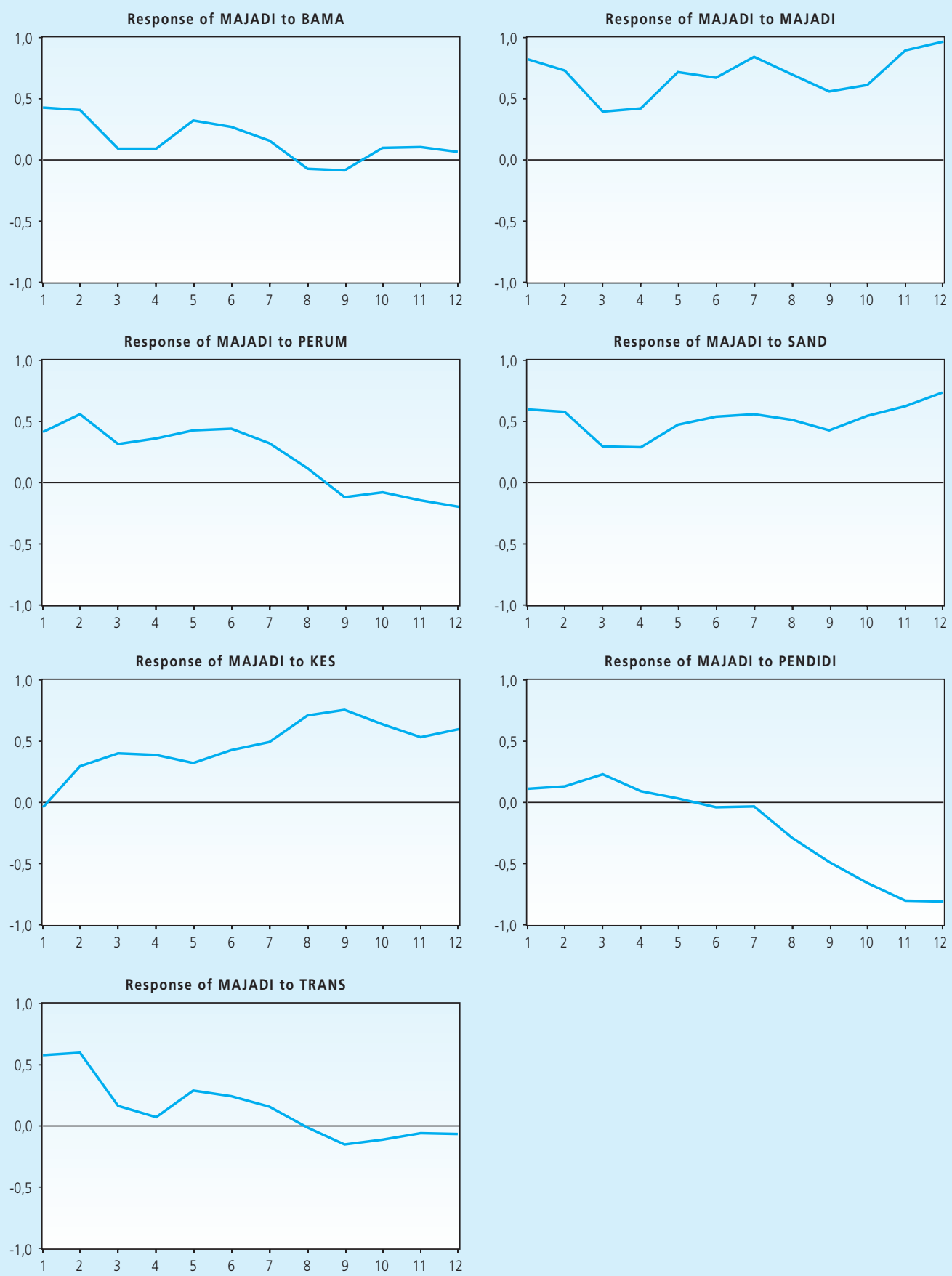

Grafik III.6

Impulse Response Function Kelompok Makanan Jadi, Minuman, Rokok, dan Tembakau 


\section{Tabel III.8}

Impulse Response Function Kelompok Makanan Jadi, Minuman, Rokok, dan Tembakau

\begin{tabular}{c|r|r|r|r|r|r|r} 
Period & BAMA & MAJADI & PERUM & \multicolumn{1}{c|}{ SAND } & \multicolumn{1}{c}{ KES } & \multicolumn{1}{c}{ PENDIDI } & TRANS \\
1 & 0,4243 & 0,8138 & 0,4046 & 0,5890 & $-0,0472$ & 0,1079 & 0,5723 \\
2 & 0,3992 & 0,7298 & 0,5520 & 0,5729 & 0,2866 & 0,1281 & 0,5932 \\
3 & 0,0804 & 0,3877 & 0,3096 & 0,2871 & 0,4009 & 0,2221 & 0,1576 \\
4 & 0,0849 & 0,4169 & 0,3552 & 0,2846 & 0,3890 & 0,0883 & 0,0724 \\
5 & 0,3175 & 0,7170 & 0,4222 & 0,4704 & 0,3127 & 0,0255 & 0,2831 \\
6 & 0,2632 & 0,6648 & 0,4359 & 0,5333 & 0,4272 & $-0,0431$ & 0,2407 \\
7 & 0,1553 & 0,8334 & 0,3162 & 0,5543 & 0,4894 & $-0,0407$ & 0,1541 \\
8 & $-0,0782$ & 0,6882 & 0,1130 & 0,5070 & 0,7065 & $-0,2990$ & $-0,0207$ \\
9 & $-0,0877$ & 0,5505 & $-0,1252$ & 0,4235 & 0,7548 & $-0,4918$ & $-0,1549$ \\
10 & 0,0890 & 0,6020 & $-0,0822$ & 0,5427 & 0,6290 & $-0,6594$ & $-0,1177$ \\
11 & 0,0953 & 0,8848 & $-0,1503$ & 0,6182 & 0,5246 & $-0,8038$ & $-0,0629$ \\
12 & 0,0558 & 0,9567 & $-0,2043$ & 0,7332 & 0,5937 & $-0,8078$ & $-0,0731$
\end{tabular}

\section{III.2.2. Variance Decomposition Harga Kelompok Makanan, Minuman, Rokok, dan Tembakau}

Berdasarkan tabel di atas, memperlihatkan bahwa kontribusi shock pada harga kelompok MAJADI pada bulan pertama didominasi oleh variabel dirinya sendiri $(72,82 \%)$, dan kemudian disusul oleh harga kelompok BAMA $(27,18 \%)$. Hal ini menunjukkan betapa sangat bergantungnya produksi kelompok MAJAD/ terhadap input yang berasal dari kelompok BAMA, sehingga peningkatan harga pada kelompok BAMA langsung berkontribusi cukup besar pada peningkatan harga di kelompok MAJADI pada bulan pertama ke depan.

Kelompok TRANS mulai berkontribusi cukup besar pada shock harga dari kelompok MAJADImulai bulan ke-4 dengan kontribusi sebesar 20,49\%, dan pada bulan tersebut kontribusi shock dari harga kelompok BAMA mulai menurun yaitu sebesar 1,63\%. Memasuki bulan ke6 kontribusi shock dari kelompok MAJADI itu sendiri juga mulai menurun menjadi 43,05\% seiring dengan penyesuaian-penyesuaian yang dilakukan oleh masyarkat terutama dengan pemilihan barang substitusi tertentu menyikapi kenaikan harga pada suatu barang di kelompok ini. Sedangkan kontribusi dari harga kelompok TRANS semakin besar $(26,42 \%)$ terkait dengan distribusi dan pemasaran yang terus dilakukan pada kelompok MAJADI sehingga kontribusi harga pada kelompok TRANS semakin besar. Hingga akhir tahun di bulan ke-12 kedua penyumbang terbesar shock dari harga pada kelompok MAJADI adalah dirinya sendiri dan kelompok TRANS, yaitu 37,37\% dan 20,52\%. 


\section{Tabel III.9}

Variance Decomposition Harga Kelompok Makanan, Minuman, Rokok, dan Tembakau

\begin{tabular}{c|l|r|r|r|r|r|r|r} 
Period & S.E. & BAMA & MAJADI & PERUM & SAND & \multicolumn{1}{|c|}{ KES } & PENDIDI & TRANS \\
\hline 1 & 0,8138 & 27,1793 & $\mathbf{7 2 , 8 2 0 7}$ & 0,0000 & 0,0000 & 0,0000 & 0,0000 & 0,0000 \\
2 & 1,1622 & 25,1267 & 63,3829 & 3,5412 & 0,1908 & 7,2602 & 0,0995 & 0,3988 \\
3 & 1,3703 & 18,4171 & $\mathbf{5 4 , 3 3 3 4}$ & 4,0982 & 0,2428 & 12,3814 & 2,9665 & 7,5606 \\
4 & 1,6271 & 13,3353 & 45,7423 & 4,5770 & 0,1766 & 13,2486 & 2,4268 & 20,4934 \\
5 & 1,8971 & 12,6104 & 45,2502 & 3,6060 & 0,2237 & 13,1304 & 1,7954 & 23,3839 \\
6 & 2,1613 & 11,1993 & 43,0454 & 3,2406 & 0,3921 & 14,1015 & 1,6023 & 26,4188 \\
7 & 2,4944 & 8,7954 & 44,8121 & 2,4603 & 0,3053 & 14,2360 & 1,2273 & 28,1637 \\
8 & 2,8141 & 6,9879 & 44,4237 & 2,2326 & 0,6243 & 16,5212 & 1,7701 & 27,4402 \\
9 & 3,1101 & 5,8005 & 41,4174 & 3,2538 & 0,8733 & 19,7473 & 3,4097 & 25,4980 \\
10 & 3,4218 & 4,8597 & 37,8356 & 3,9923 & 1,2965 & 20,5670 & 6,7898 & 24,6592 \\
11 & 3,7990 & 4,0054 & 37,3312 & 5,7310 & 1,1573 & 19,2594 & 10,0334 & 22,4824 \\
12 & 4,1985 & 3,2972 & $\mathbf{3 7 , 2 6 9 1}$ & 7,3562 & 1,3016 & 18,2773 & 11,9755 & $\mathbf{2 0 , 5 2 3 2}$ \\
\end{tabular}

\section{III.3. Kelompok Perumahan, Air, Listrik, Gas, dan Bahan Bakar (PERUM)}

\section{III.3.1. Impulse Response Function Harga Kelompok Perumahan, Air, Listrik, Gas, dan Bahan Bakar}

Hasil IRF di harga kelompok PERUM jika terjadi shock sebesar 1 S.D. pada masing-masing variabel, pada bulan ke-1 ke depan harga kelompok PERUM dan TRANS yang menyebabkan peningkatan harga tertinggi dibandingkan kelompok lainnya, yaitu 0,84\% dan 0,67\%. Namun shock pada kelompok TRANS mengalami penurunan memasuki bulan ke-4 hingga bulan ke-6,

Response to Generalized One S.D. Innovations

Response of PERUM to BAMA

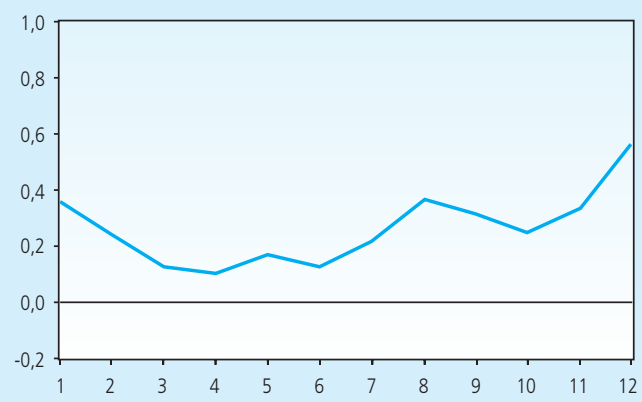

Response of PERUM to MAJADI

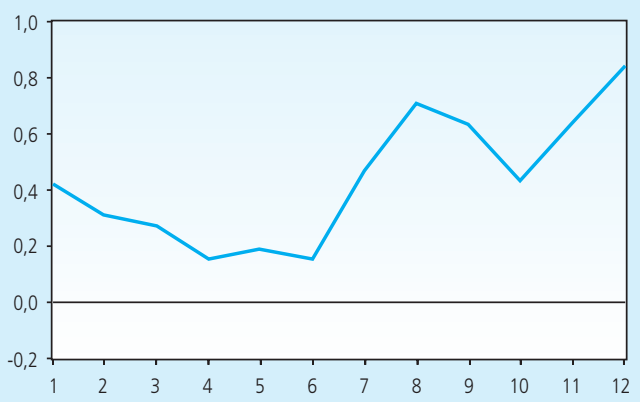

Grafik III.7

Impulse Response Function Harga Kelompok Perumahan, Air, Listrik, Gas dan Bahan Bakar 
Response to Generalized One S.D. Innovations
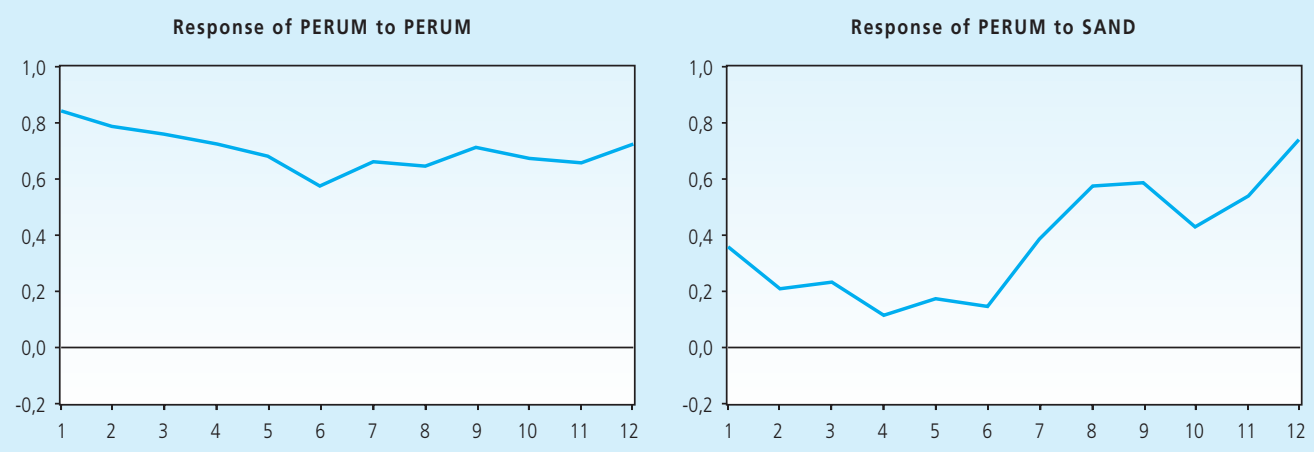

Response of PERUM to KES

Response of PERUM to PENDIDI
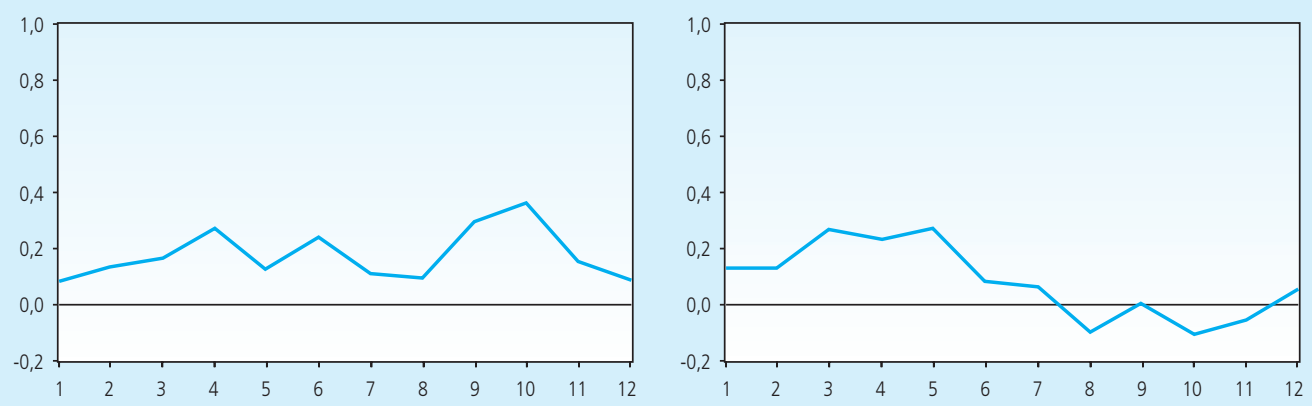

Response of PERUM to TRANS

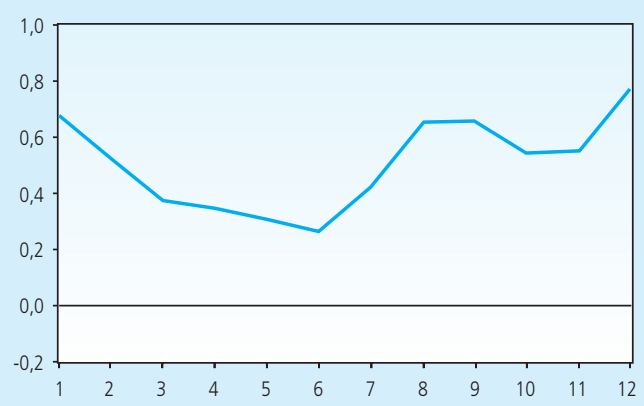

Grafik III.7

Impulse Response Function Harga Kelompok Perumahan, Air, Listrik, Gas dan Bahan Bakar (lanjutan)

dan kemudian berangsur meningkat kembali hingga ke 6 bulan berikutnya dengan shock sekitar 0,54\% hingga 0,77\%. Sedangkan pada kelompok PERUM sendiri persisten dengan shock yang cukup tinggi dari pertengahan tahun hingga akhir tahun sebesar 0,64\% hingga 0,72\%. 
Tabel III.10

Impulse Response Function Harga Kelompok Perumahan, Air, Listrik, Gas dan Bahan Bakar

\begin{tabular}{c|r|r|r|r|r|r|r} 
Period & BAMA & MAJADI & PERUM & \multicolumn{1}{l|}{ SAND } & \multicolumn{1}{l}{ KES } & PENDIDI & TRANS \\
1 & 0,3561 & 0,4175 & 0,8399 & 0,3564 & 0,0793 & 0,1260 & 0,6725 \\
2 & 0,2368 & 0,3091 & 0,7874 & 0,2052 & 0,1299 & 0,1270 & 0,5196 \\
3 & 0,1213 & 0,2683 & 0,7604 & 0,2293 & 0,1637 & 0,2665 & 0,3714 \\
4 & 0,0972 & 0,1515 & 0,7197 & 0,1100 & 0,2688 & 0,2302 & 0,3448 \\
5 & 0,1673 & 0,1864 & 0,6761 & 0,1730 & 0,1233 & 0,2677 & 0,3027 \\
6 & 0,1229 & 0,1518 & 0,5745 & 0,1450 & 0,2383 & 0,0809 & 0,2600 \\
7 & 0,2139 & 0,4668 & 0,6604 & 0,3856 & 0,1068 & 0,0598 & 0,4199 \\
8 & 0,3666 & 0,7049 & 0,6439 & 0,5742 & 0,0907 & $-0,1009$ & 0,6494 \\
9 & 0,3114 & 0,6325 & 0,7078 & 0,5850 & 0,2924 & 0,0026 & 0,6560 \\
10 & 0,2450 & 0,4306 & 0,6706 & 0,4284 & 0,3620 & $-0,1102$ & 0,5427 \\
11 & 0,3314 & 0,6361 & 0,6531 & 0,5396 & 0,1525 & $-0,0609$ & 0,5514 \\
12 & 0,5612 & 0,8414 & 0,7192 & 0,7403 & 0,0844 & 0,0521 & 0,7713
\end{tabular}

Harga kelompok PERUM sendiri secara persisten memberikan shock peningkatan harga pada dirinya sendiri hingga akhir periode (bulan ke-12) dengan rata-rata menyebabkan peningkatan harga sebesar $0,70 \%$. Hal ini terkait dengan sifat pada kelompok komoditas ini yang banyak penentuan harganya banyak dipengaruhi oleh kebijakan pemerintah (administered prices) terutama dalam sub-kelompok bahan bakar, penerangan, dan air. Selain itu pada subkelompok biaya tempat tinggal juga akan berlangsung secara persisten terutama sifatnya baik tanah atau rumah yang banyak dijadikan sebagai sarana investasi.

Dampak persistensi peningkatan harga kelompok PERUM juga terjadi akibat shock dari kelompok BAMA, MAJADI, dan SAND, di mana menunjukkan dampak pada pergerakan harga PERUM semakin menjauh dari harga keseimbangannya.

\section{III.3.2. Variance Decomposition Harga Kelompok Perumahan, Air, Listrik, Gas, dan Bahan Bakar}

Hasil FEDV menunjukkan bahwa kontribusi shock pada fluktuasi harga kelompok PERUM didominasi oleh variabel itu sendiri, di mana mempunyai andil dari bulan ke-1 hingga bulan ke11 ke depan dengan kontribusi pada kisaran 54,33-75,77\%. Namun di akhir periode pada bulan ke-12 kontribusinya hanya menjadi 49,77\% dan mulai meningkat kontribusi dari harga kelompok MAJAD/ sebesar 22,93\%.

Fenomena ini menunjukkan bahwa pada pembentuk harga kelompok PERUM di mana terdapat sub-kelompok yang harganya berdasarkan administered prices maka penyesuaian harga setelah terjadi shock akan sangat bergantung pada kebijakan pemerintah itu sendiri. 
Yaitu keputusan untuk menurunkan harga pada sub-kelompok yang masuk dalam administered prices, terutama pada sub-kelompok bahan bakar, penerangan, dan air. Selain itu, dari hasil di atas menunjukkan bahwa peran kelompok TRANS dalam mempengaruhi pergerakan harga pada kelompok PERUM tidak terlalu besar. Kebijakan pemerintah yang mengakibatkan peningkatan harga secara bersamaan pada kedua kelompok ini adalah sebuah kondisi tersulit yang harus dihadapi masyarakat dalam mempertahankan daya belinya. Dengan demikian, meskipun secara nilai ekonomis biaya input kelompok PERUM mengalami peningkatan, namun pemerintah cenderung akan menahan peningkatan harganya, terutama apabila pertimbangan strategis tidak memungkinkan untuk meningkatkan harga pada saat itu.

Tabel III.11

Variance Decomposition Harga Kelompok Perumahan, Air, Listrik, Gas, dan Bahan Bakar

\begin{tabular}{c|r|r|r|r|r|r|r|r} 
Period & S.E. & \multicolumn{1}{|c|}{ BAMA } & MAJADI & PERUM & SAND & KES & PENDIDI & TRANS \\
1 & 0,8399 & 17,9696 & 10,4704 & 71,5600 & 0,0000 & 0,0000 & 0,0000 & 0,0000 \\
2 & 1,1694 & 13,3703 & 8,8635 & 75,7671 & 0,5782 & 0,0441 & 0,1970 & 1,1799 \\
3 & 1,4795 & 9,0258 & 8,1766 & 72,7727 & 0,3887 & 0,0276 & 2,1143 & 7,4943 \\
4 & 1,7091 & 7,0864 & 6,6054 & 74,1421 & 0,3502 & 0,6054 & 2,9501 & 8,2603 \\
5 & 1,9012 & 6,5012 & 5,7116 & 72,3692 & 0,2831 & 0,4937 & 3,5484 & 11,0928 \\
6 & 2,0227 & 6,1124 & 5,3042 & 72,1060 & 0,2529 & 0,9723 & 3,1648 & 12,0874 \\
7 & 2,1650 & 6,3114 & 8,3280 & 68,5858 & 0,2937 & 0,8488 & 2,7817 & 12,8506 \\
8 & 2,3170 & 8,0142 & 14,0224 & 62,1289 & 0,3786 & 0,7895 & 3,4418 & 11,2246 \\
9 & 2,4667 & 8,6651 & 17,3598 & 58,4465 & 0,8491 & 1,5056 & 3,2584 & 9,9156 \\
10 & 2,5898 & 8,7556 & 17,6263 & 57,2758 & 1,0819 & 2,6246 & 3,6086 & 9,0273 \\
11 & 2,7134 & 9,4682 & 20,0615 & 54,3318 & 1,1248 & 2,5283 & 3,7417 & 8,7438 \\
12 & 2,8717 & 12,2714 & 22,9251 & 49,7695 & 1,2437 & 2,4010 & 3,5447 & 7,8446 \\
& & & & & & &
\end{tabular}

\section{III.4. Kelompok Sandang (SAND)}

\section{III.4. 1. Impulse Response Function Harga Kelompok Sandang}

Apabila terjadi shock positif sebesar 1 S.D. pada masing-masing harga kelompok komoditas, pada bulan pertama ke depan, harga kelompok BAMA menyebabkan peningkatan harga pada kelompok SAND sebesar 0,26\%, sedangkan dampak dari kelompok MAJADI adalah sebesar 0,35\%, kelompok PERUM 0,21\%, kelompok SAND itu sendiri 0,48\%, kelompok TRANS 0,32\%, kelompok PENDIDI 0,12\%, sedangkan kelompok KES menyebabkan penurunan harga $-0,02 \%$. Di bulan ke-6, selain variabel dirinya sendiri, kelompok MAJADI dan TRANS yang mengakibatkan peningkatan harga terbesar pada kelompok SAND, masing-masing sebesar 0,34\% dan 0,27\%. Hal ini menunjukkan bahwa shock yang terjadi pada kelompok komoditas lain ternyata juga berdampak pada harga kelompok SAND. 
Berbagai shock dari harga kelompok komoditas terhadap harga kelompok SAND mayoritas menyebabkan peningkatan harga pada kelompok ini secara persisten hingga sepanjang 12 bulan ke depan, kecuali pada kelompok KES dan PERUM yang menunjukkan kecenderungan menurun pada akhir tahun.

\section{Response to Generalized One S.D. Innovations}

Response of SAND to BAMA

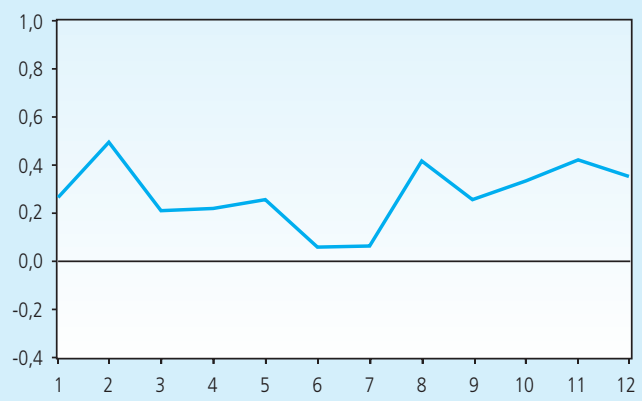

Response of SAND to PERUM

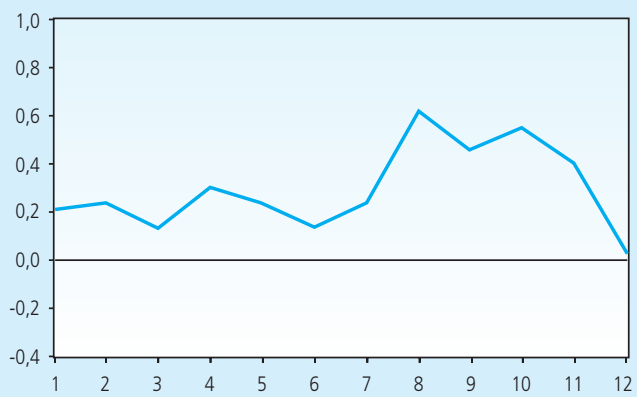

Response of SAND to KES

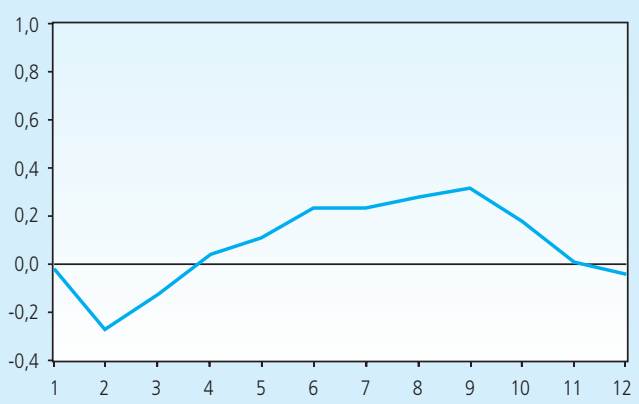

Response of SAND to MAJADI

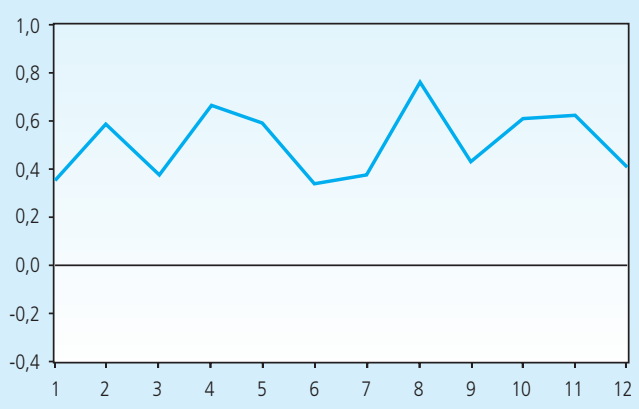

Response of SAND to SAND

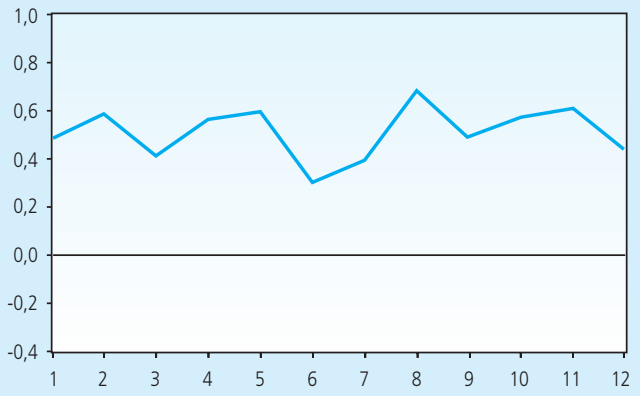

Response of SAND to PENDIDI

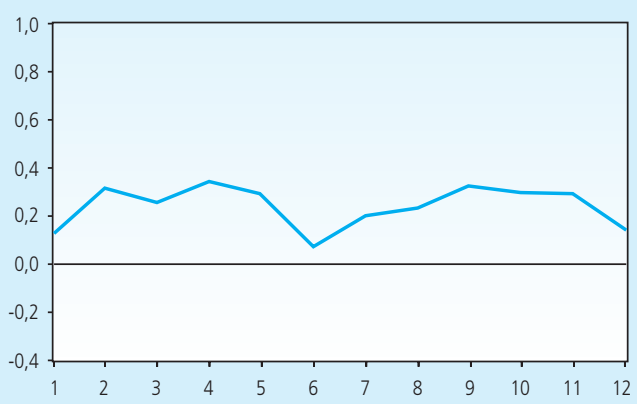

Grafik III.8

Impulse Response Function Harga Kelompok Sandang 


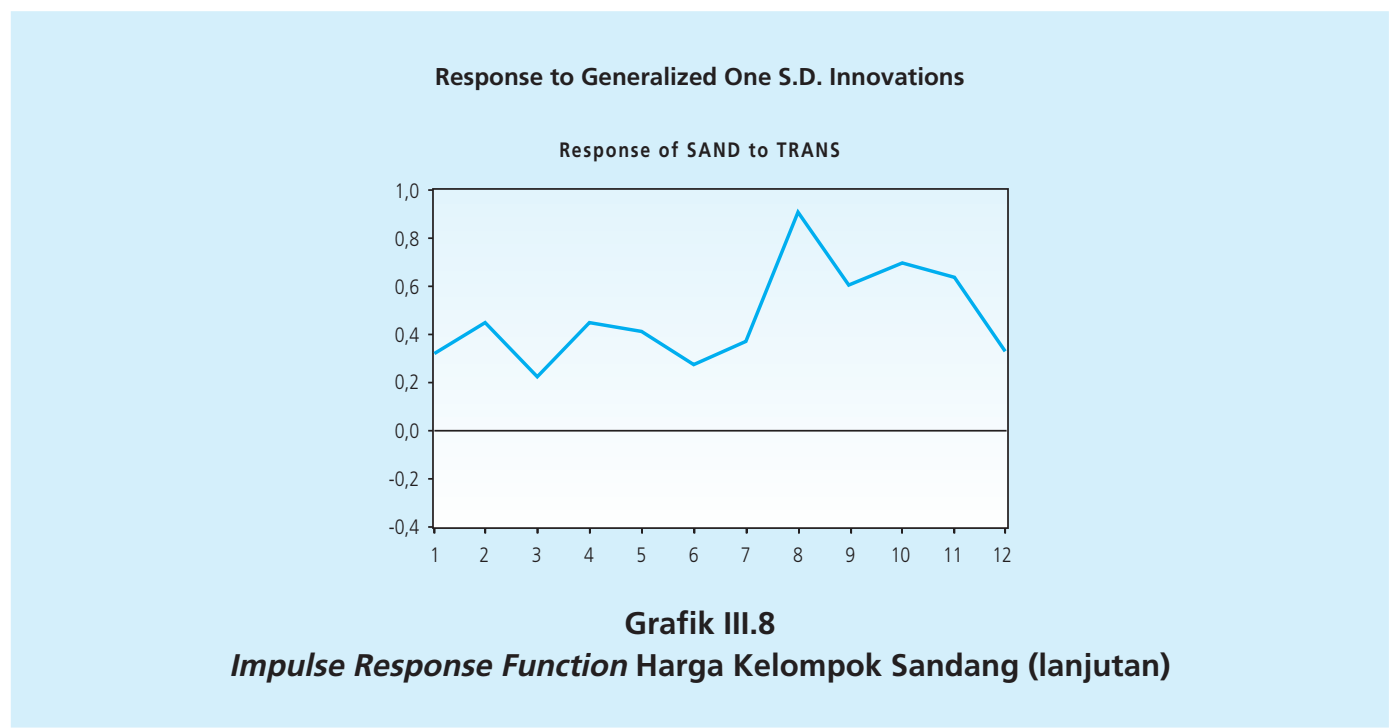

\begin{tabular}{c|c|c|c|c|c|c|c|}
\multicolumn{8}{c}{ Tabel III.12 } \\
Period & BAMA & MAJADI & PERUM & SAND & KES & PENDIDI & TRANS \\
\hline 1 & 0,2645 & 0,3503 & 0,2054 & 0,4840 & $-0,0229$ & 0,1244 & 0,3168 \\
2 & 0,4943 & 0,5849 & 0,2374 & 0,5850 & $-0,2772$ & 0,3114 & 0,4435 \\
3 & 0,2058 & 0,3732 & 0,1310 & 0,4069 & $-0,1285$ & 0,2544 & 0,2252 \\
4 & 0,2142 & 0,6588 & 0,3020 & 0,5622 & 0,0374 & 0,3386 & 0,4457 \\
5 & 0,2545 & 0,5897 & 0,2389 & 0,5940 & 0,1052 & 0,2929 & 0,4102 \\
6 & 0,0579 & 0,3378 & 0,1349 & 0,2993 & 0,2307 & 0,0716 & 0,2731 \\
7 & 0,0630 & 0,3718 & 0,2369 & 0,3878 & 0,2315 & 0,1948 & 0,3696 \\
8 & 0,4113 & 0,7572 & 0,6159 & 0,6795 & 0,2755 & 0,2316 & 0,9062 \\
9 & 0,2532 & 0,4264 & 0,4548 & 0,4870 & 0,3113 & 0,3243 & 0,6000 \\
10 & 0,3333 & 0,6082 & 0,5459 & 0,5704 & 0,1735 & 0,2950 & 0,6946 \\
11 & 0,4171 & 0,6208 & 0,4011 & 0,6065 & 0,0057 & 0,2896 & 0,6341 \\
12 & 0,3515 & 0,4047 & 0,0259 & 0,4340 & $-0,0462$ & 0,1375 & 0,3274 \\
\hline
\end{tabular}

\section{III.4.2. Variance Decomposition Harga Kelompok Sandang}

Berdasarkan hasil FEDV menunjukkan bahwa kontribusi shock pada perubahan harga kelompok SAND di bulan pertama ke depan banyak dipengaruhi oleh variabel dirinya sendiri sebesar 43,58\%. Namun di bulan ke-3 peran variabel SAND itu sendiri semakin berkurang $(18,54 \%)$ dan lebih banyak dipengaruhi oleh harga kelompok BAMA dan MAJAD/ sebesar $37,08 \%$ dan $31,83 \%$. Hingga akhir periode di bulan ke-12 pun demikian, pengaruh terbesar berasal dari kelompok MAJADI (42,20\%) dan BAMA (19,92\%). Hal ini menunjukkan bahwa fluktuasi harga pada kelompok SAND dalam beberapa bulan kedepannya banyak dipengaruhi 
oleh harga kelompok MAJADI dan BAMA. Sifat penentuan harga dari SAND berdasarkan hasil FEDV ini memperlihatkan bahwa lebih adaptif terhadap harga kelompok BAMA dan MAJADI dibandingkan dengan dirinya sendiri.

\begin{tabular}{|c|c|c|c|c|c|c|c|c|}
\hline \multicolumn{9}{|c|}{$\begin{array}{c}\text { Tabel III.13 } \\
\text { Variance Decomposition Harga Kelompok Sandang }\end{array}$} \\
\hline Period & S.E. & BAMA & MAJADI & PERUM & SAND & KES & PENDIDI & TRANS \\
\hline 1 & 0,4840 & 29,8640 & 26,4500 & 0,0964 & 43,5896 & 0,0000 & 0,0000 & 0,0000 \\
\hline 2 & 0,8515 & 43,3396 & 28,8274 & 1,8155 & 18,7293 & 4,1103 & 3,0918 & 0,0861 \\
\hline 3 & 0,9807 & 37,0820 & 31,8311 & 1,8423 & 18,5475 & 4,4986 & 5,2952 & 0,9032 \\
\hline 4 & 1,2342 & 26,4224 & 47,0882 & 1,1645 & 13,7119 & 2,8437 & 8,1986 & 0,5708 \\
\hline 5 & 1,4173 & 23,2613 & 49,9890 & 1,0074 & 14,1426 & 2,8338 & 8,3287 & 0,4373 \\
\hline 6 & 1,4945 & 21,0698 & 50,7754 & 0,9084 & 13,4192 & 4,5873 & 7,6494 & 1,5905 \\
\hline 7 & 1,5972 & 18,6031 & 50,6434 & 1,1604 & 13,6687 & 5,2264 & 7,7366 & 2,9615 \\
\hline 8 & 1,8941 & 17,9442 & 47,2889 & 2,9898 & 10,6244 & 5,8134 & 5,8566 & 9,4827 \\
\hline 9 & 2,0362 & 17,0724 & 43,7870 & 4,4619 & 10,6548 & 7,0980 & 6,4946 & 10,4313 \\
\hline 10 & 2,1795 & 17,2395 & 43,6761 & 5,5871 & 9,9678 & 6,6733 & 6,4276 & 10,4287 \\
\hline 11 & 2,2969 & 18,8193 & 43,5612 & 5,1656 & 9,7430 & 6,0527 & 6,2514 & 10,4068 \\
\hline 12 & 2,3676 & 19,9158 & 42,1993 & 5,9311 & 9,7207 & 5,8185 & 5,9069 & 10,5078 \\
\hline
\end{tabular}

\section{III.5. Kelompok Kesehatan (KES)}

\section{III.5.1. Impulse Response Function Harga Kelompok Kesehatan}

Shock dari variabel harga kelompok KES itu sendiri yang terjadi peningkatan harga paling besar dibandingkan dengan kelompok lainnya di bulan pertama, yaitu sebesar 0,51\%. Pada bulan ke-6 harga kelompok PERUM turut memberikan shock pada peningkatan harga yang

Response to Generalized One S.D. Innovations

Response of KES to BAMA

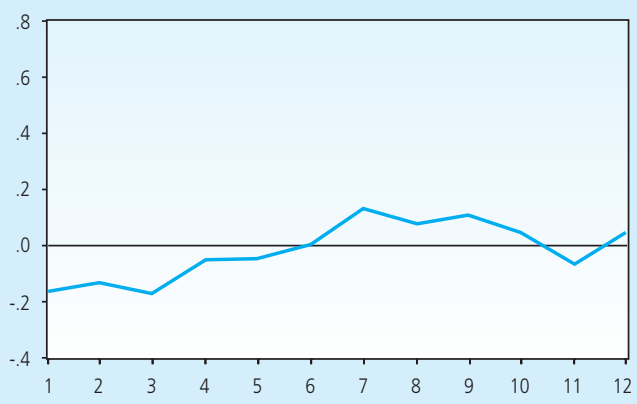

Response of KES to MAJADI

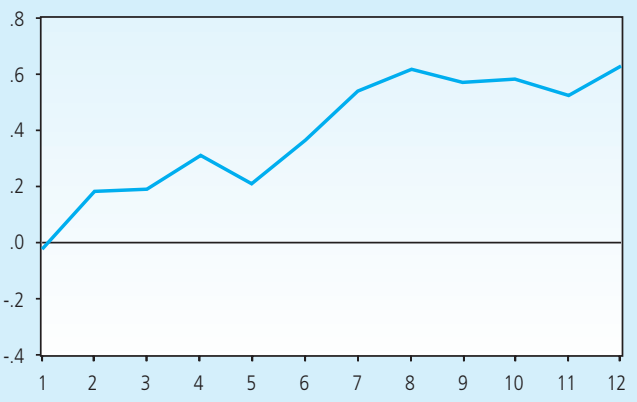

Grafik III.9

Impulse Response Function Harga Kelompok Kesehatan 


\section{Response to Generalized One S.D. Innovations}
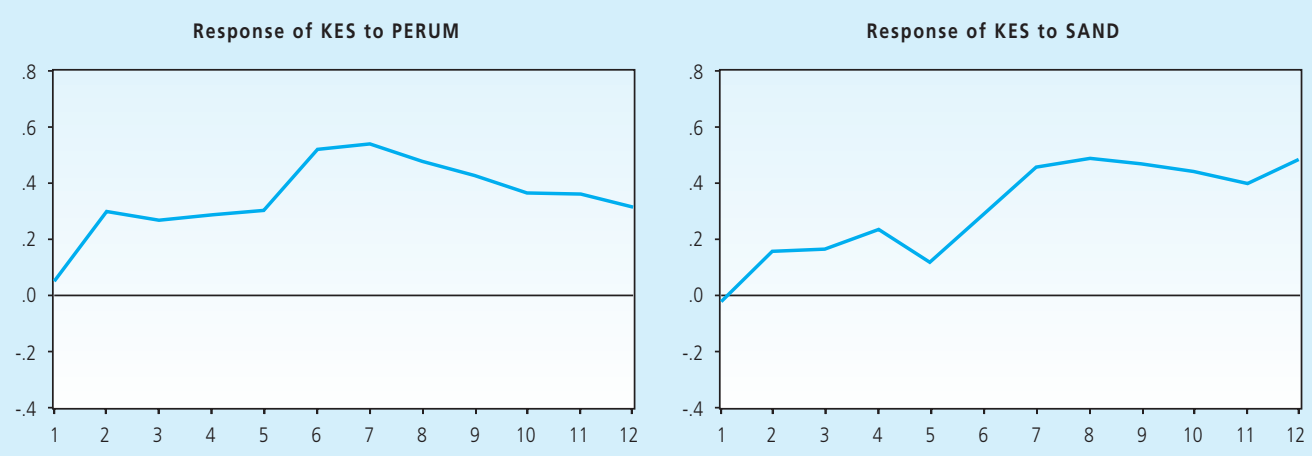

Response of KES to KES

Response of KES to PENDIDI
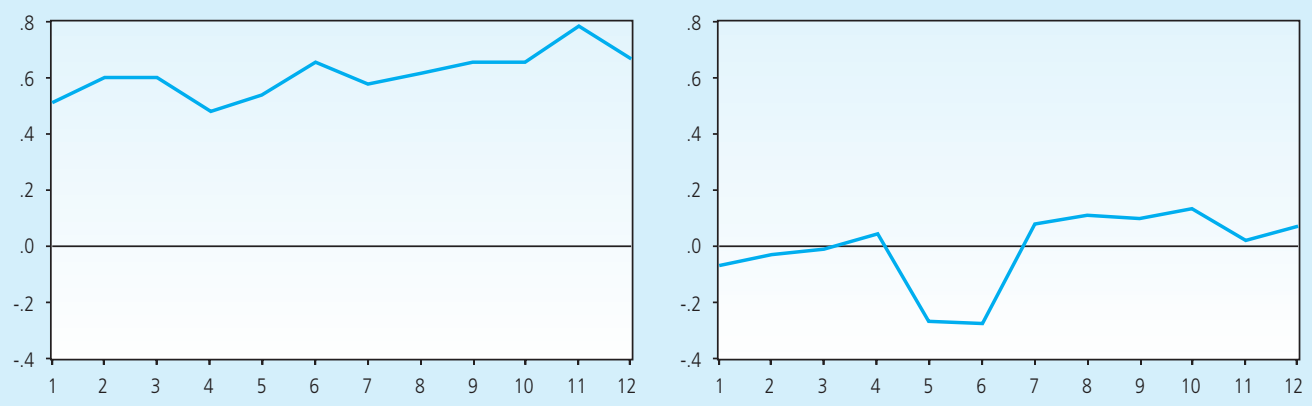

Response of KES to TRANS

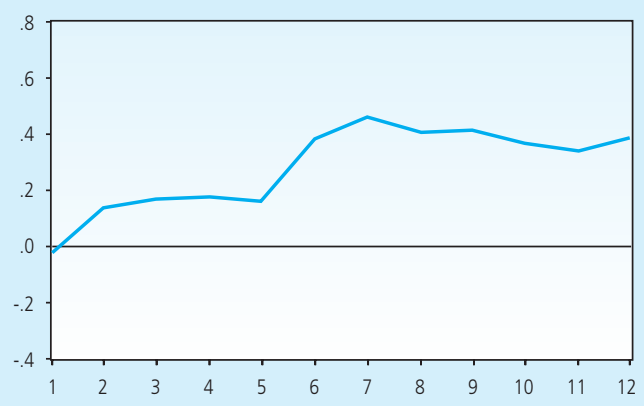

Grafik III.9

Impulse Response Function Harga Kelompok Kesehatan (lanjutan)

cukup besar yaitu 0,52\%, di mana penyediaan jasa kesehatan dan produksi barang-barang medis tidak dapat terlepas dari input-input pada kelompok PERUM seperti sub-kelompok bahan bakar, penerangan, dan air. Pada bulan ke-12 shock pada harga kelompok MAJADI juga mengakibatkan peningkatan harga cukup besar pada kelompok KES sebesar 0,63\%. 


\begin{tabular}{|c|c|c|c|c|c|c|c|}
\hline Period & BAMA & MAJADI & PERUM & SAND & KES & PENDIDI & TRANS \\
\hline 1 & $-0,167$ & $-0,029$ & 0,048 & $-0,024$ & 0,508 & $-0,072$ & $-0,023$ \\
\hline 2 & $-0,134$ & 0,181 & 0,295 & 0,157 & 0,601 & $-0,030$ & 0,135 \\
\hline 3 & $-0,173$ & 0,190 & 0,264 & 0,167 & 0,601 & $-0,012$ & 0,165 \\
\hline 4 & $-0,054$ & 0,307 & 0,283 & 0,234 & 0,476 & 0,041 & 0,171 \\
\hline 5 & $-0,052$ & 0,208 & 0,299 & 0,116 & 0,539 & $-0,265$ & 0,159 \\
\hline 6 & 0,002 & 0,361 & 0,520 & 0,287 & 0,655 & $-0,279$ & 0,381 \\
\hline 7 & 0,131 & 0,540 & 0,540 & 0,454 & 0,579 & 0,076 & 0,460 \\
\hline 8 & 0,076 & 0,615 & 0,478 & 0,486 & 0,615 & 0,109 & 0,405 \\
\hline 9 & 0,107 & 0,570 & 0,426 & 0,467 & 0,655 & 0,096 & 0,412 \\
\hline 10 & 0,044 & 0,583 & 0,362 & 0,440 & 0,654 & 0,131 & 0,364 \\
\hline 11 & $-0,071$ & 0,525 & 0,359 & 0,396 & 0,784 & 0,020 & 0,337 \\
\hline 12 & 0,045 & 0,629 & 0,310 & 0,481 & 0,667 & 0,069 & 0,385 \\
\hline
\end{tabular}

\section{III.5.2. Variance Decomposition Harga Kelompok Kesehatan}

Berdasarkan hasil FEDV pada bulan pertama ke depan kontribusi terbesar pada perubahan harga di kelompok KES adalah variabel dirinya sendiri sebesar 81,67\%. Memasuki bulan ke-6 ke depan, kontribusi harga kelompok MAJADI menjadi cukup besar yaitu 21,88\% sedangkan harga kelompok KES itu sendiri 48,41\%. Dan komposisi kontribusi penyumbang terbesar perubahan harga ini tidak banyak berubah hingga bulan ke-12 ke depan, yaitu harga kelompok MAJADI 38,96\% dan KES 43,32\%.

Harga kelompok PERUM juga turut memberikan kontribusi pada pergerakan harga di kelompok KES ini sekitar 10,41\%-18,2\% setelah satu bulan ke depan. Namun demikian secara umum, pergerakan harga di kelompok KES ini dominan dipengaruhi oleh harga kelompok KES itu sendiri dengan range antara 42,82\% hingga $81,66 \%$.

Hasil impulse response juga menunjukkan bahwa pengaruh shock dari variabel kelompok KES itu sendiri menyebabkan peningkatan harga secara persisten selama 12 bulan ke depan. Hal ini menunjukkan bahwa peran variabel dirinya sendiri yang perlu diperhatikan jika ingin mengendalikan inflasi pada kelompok ini. Begitupula pada kelompok MAJADI dan SAND yang secara gradual menyebabkan peningkatan harga kelompok KES dengan semakin menjauhi harga keseimbangannya. 


\begin{tabular}{|c|c|c|c|c|c|c|c|c|}
\hline \multicolumn{9}{|c|}{$\begin{array}{c}\text { Tabel III.15 } \\
\text { Variance Decomposition Harga Kelompok Kesehatan }\end{array}$} \\
\hline Period & S.E. & BAMA & MAJADI & PERUM & SAND & KES & PENDIDI & TRANS \\
\hline 1 & 0,5077 & 10,7629 & 1,7532 & 5,0761 & 0,7433 & 81,6646 & 0,0000 & 0,0000 \\
\hline 2 & 0,8491 & 6,3367 & 12,5663 & 14,6502 & 1,8249 & 62,2275 & 0,0476 & 2,3467 \\
\hline 3 & 1,0848 & 6,4118 & 16,8647 & 15,3165 & 2,4939 & 57,2563 & 0,2059 & 1,4508 \\
\hline 4 & 1,2530 & 4,9889 & 22,4777 & 14,3237 & 2,3052 & 52,5830 & 0,4841 & 2,8373 \\
\hline 5 & 1,4170 & 4,0341 & 21,3388 & 14,9325 & 1,8055 & 52,1193 & 3,0840 & 2,6858 \\
\hline 6 & 1,6645 & 2,9239 & 21,8827 & 18,1974 & 1,5613 & 48,4077 & 5,0710 & 1,9561 \\
\hline 7 & 1,8729 & 2,7992 & 25,9777 & 18,0952 & 1,7333 & 45,4985 & 4,0840 & 1,8121 \\
\hline 8 & 2,0931 & 2,3714 & 31,1986 & 16,1345 & 1,8031 & 42,8173 & 3,5463 & 2,1289 \\
\hline 9 & 2,2819 & 2,2145 & 33,2351 & 14,4971 & 1,8835 & 43,1080 & 3,1632 & 1,8986 \\
\hline 10 & 2,4617 & 1,9352 & 35,6690 & 12,8508 & 1,8222 & 42,8625 & 3,1323 & 1,7280 \\
\hline 11 & 2,6514 & 1,7398 & 36,9125 & 11,6933 & 1,8332 & 43,5443 & 2,7779 & 1,4991 \\
\hline 12 & 2,8198 & 1,5637 & 38,9642 & 10,4054 & 1,8523 & 43,3205 & 2,5680 & 1,3258 \\
\hline
\end{tabular}

\section{III.6. Kelompok Pendidikan, Rekreasi, dan Olahraga (PENDIDI)}

\section{III.6.1. Impulse Response Function Harga Kelompok Pendidikan, Rekreasi, dan Olahraga}

Shock positif sebesar 1 S.D. pada bulan pertama ke depan dari setiap variabel yang menyebabkan peningkatan harga tertinggi pada harga kelompok PENDIDI adalah kelompok PENDID/ itu sendiri sebesar $1,17 \%$, kisaran di atas $1 \%$ ini terus berlangsung hingga bulan ke6 ke depan. Peningkatan terbesar juga berasal dari shock pada harga kelompok PERUM seperti di bulan ke-5 yang sebesar 0,83\%. Hal ini tentu saja terkait dengan biaya kebutuhan operasional

Response to Generalized One S.D. Innovations

Response of PENDIDI to BAMA

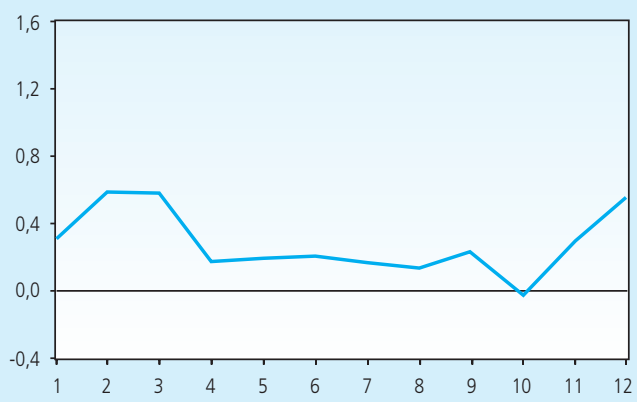

Response of PENDIDI to MAJADI

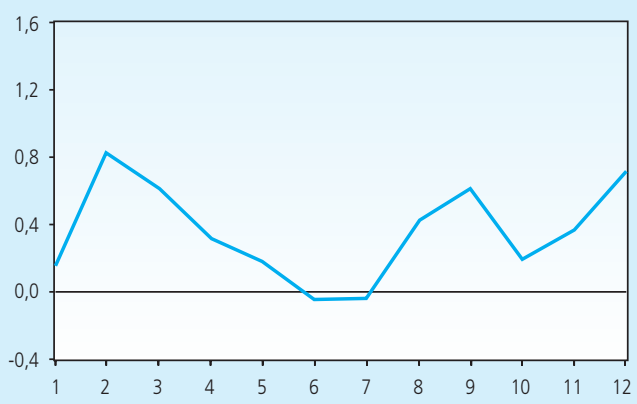

Grafik III.10 Impulse Response Function Harga Kelompok Pendidikan, Rekreasi, dan Olahraga 


\section{Response to Generalized One S.D. Innovations}
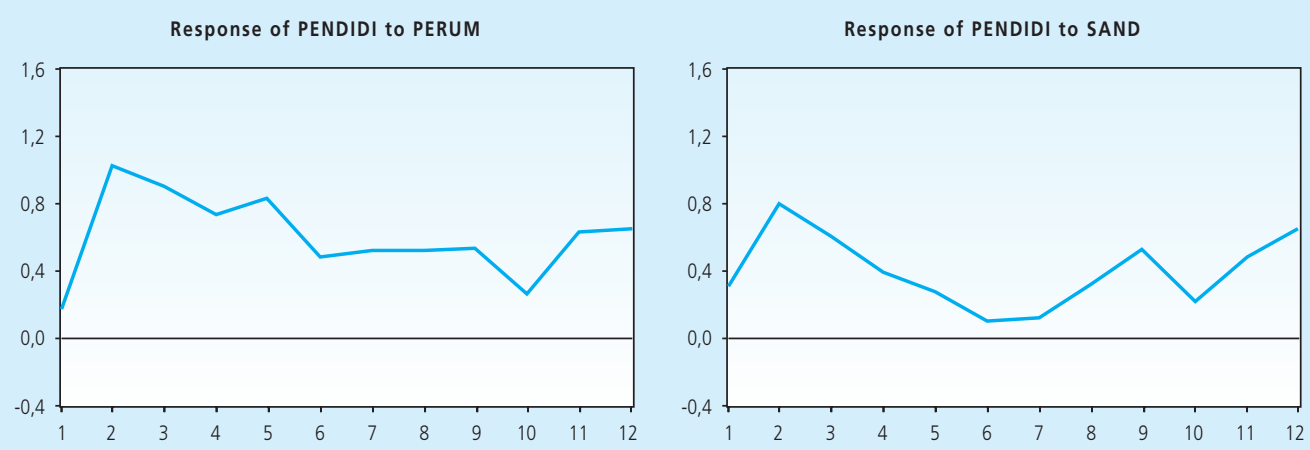

Response of PENDIDI to KES

Response of PENDIDI to PENDIDI
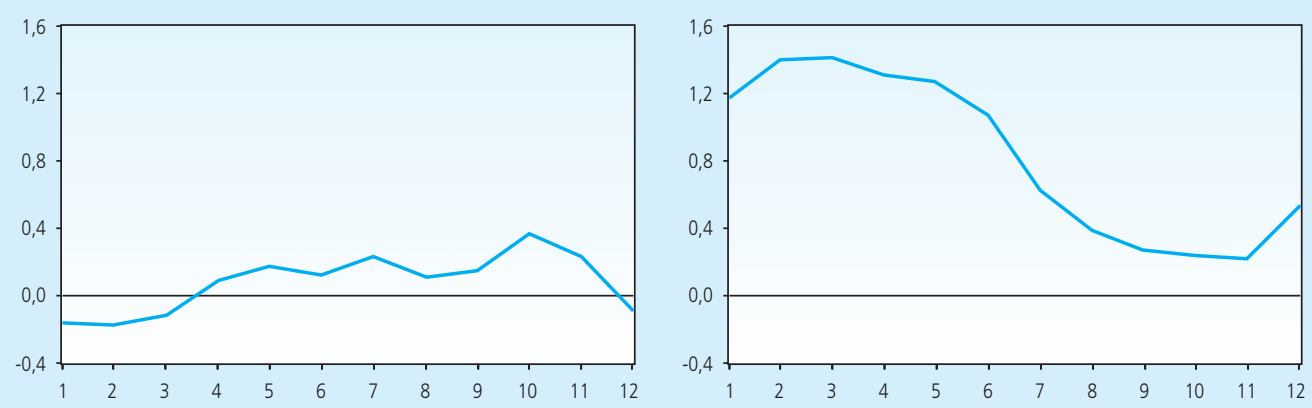

Response of PENDIDI to TRANS

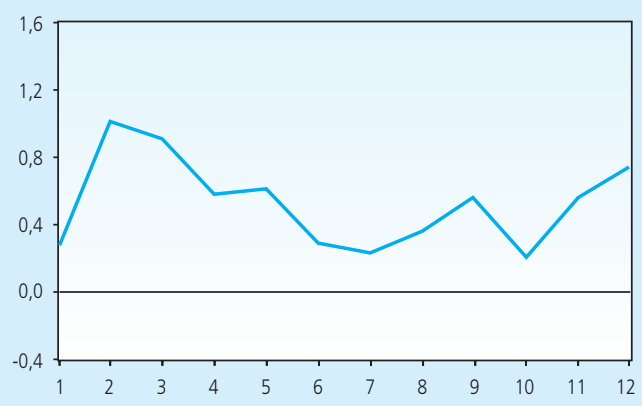

Grafik III.10

Impulse Response Function Harga Kelompok Pendidikan, Rekreasi, dan Olahraga (lanjutan)

pada kelompok KES ini terhadap sub-kelompok bahan bakar, penerangan, dan air. Selain itu juga harga kelompok SAND mengakibatkan peningkatan harga cukup tinggi pada bulan ke-2 dan ke-12 sebesar 0,80\% dan 0,65\%, di mana kebutuhan pendidikan dan olahraga tidak terlepas dengan kebutuhan di kelompok sandang, terutama yang mendukung kebutuhan terkait pelaksanaan pendidikan seperti seragam sekolah seiring dengan pola permulaan jadwal pendidikan yang dimulai pada awal tahun. 


\begin{tabular}{|c|c|c|c|c|c|c|c|}
\hline Period & BAMA & MAJADI & PERUM & SAND & KES & PENDIDI & TRANS \\
\hline 1 & 0,3121 & 0,1556 & 0,1760 & 0,3016 & $-0,1663$ & 1,1733 & 0,2771 \\
\hline 2 & 0,5863 & 0,8220 & 1,0226 & 0,7961 & $-0,1781$ & 1,3952 & 1,0113 \\
\hline 3 & 0,5782 & 0,6123 & 0,8999 & 0,5990 & $-0,1190$ & 1,4098 & 0,9117 \\
\hline 4 & 0,1755 & 0,3148 & 0,7324 & 0,3871 & 0,0850 & 1,3066 & 0,5811 \\
\hline 5 & 0,1934 & 0,1798 & 0,8285 & 0,2750 & 0,1696 & 1,2686 & 0,6142 \\
\hline 6 & 0,2090 & $-0,0401$ & 0,4837 & 0,0965 & 0,1162 & 1,0711 & 0,2927 \\
\hline 7 & 0,1672 & $-0,0392$ & 0,5255 & 0,1166 & 0,2264 & 0,6181 & 0,2308 \\
\hline 8 & 0,1368 & 0,4269 & 0,5218 & 0,3149 & 0,1052 & 0,3805 & 0,3613 \\
\hline 9 & 0,2359 & 0,6100 & 0,5338 & 0,5256 & 0,1414 & 0,2660 & 0,5602 \\
\hline 10 & $-0,0235$ & 0,1920 & 0,2641 & 0,2116 & 0,3602 & 0,2344 & 0,2107 \\
\hline 11 & 0,2990 & 0,3657 & 0,6337 & 0,4773 & 0,2284 & 0,2134 & 0,5623 \\
\hline 12 & 0,5569 & 0,7170 & 0,6546 & 0,6450 & $-0,0945$ & 0,5289 & 0,7429 \\
\hline
\end{tabular}

\section{III.6.2. Variance Decomposition Harga Kelompok Pendidikan, Rekreasi, dan Olahraga}

Hasil FEDV juga mengkonfirmasi analisis pada hasil IRF di mana pada bulan ke-1 kontribusi terbesar penyumbang gejolak harga pada kelompok PENDIDI adalah variabel dirinya sendiri. Selain itu juga kontribusi yang cukup besar berasal dari kelompok PERUM dengan range setelah bulan ke-1 antara $11,30 \%$ hingga 21,12\% yang menunjukkan bahwa pelaksanaan operasional pendidikan banyak juga membutuhkan input dari kelompok komoditas ini.

\begin{tabular}{|c|c|c|c|c|c|c|c|c|}
\hline \multicolumn{9}{|c|}{$\begin{array}{cc}\text { Tabel III.17 } \\
\text { Variance Decomposition Harga Kelompok Per }\end{array}$} \\
\hline Period & S.E. & BAMA & MAJADI & PERUM & SAND & KES & PENDIDI & TRANS \\
\hline 1 & 1,1733 & 7,0753 & 0,0050 & 0,2186 & 2,9762 & 0,7624 & 88,9624 & 0,0000 \\
\hline 2 & 2,0396 & 10,6053 & 8,8016 & 11,3039 & 2,1170 & 1,9283 & 65,2418 & 0,0023 \\
\hline 3 & 2,5848 & 11,6071 & 7,4663 & 13,0679 & 1,5165 & 1,5124 & 64,7023 & 0,1275 \\
\hline 4 & 2,9794 & 9,0831 & 6,3908 & 15,0104 & 1,6166 & 1,1921 & 66,5878 & 0,1192 \\
\hline 5 & 3,3409 & 7,5592 & 5,1596 & 18,3669 & 1,4727 & 0,9515 & 66,3934 & 0,0968 \\
\hline 6 & 3,5546 & 7,0233 & 4,7991 & 18,4798 & 1,3568 & 0,9031 & 67,2383 & 0,1997 \\
\hline 7 & 3,6717 & 6,7899 & 4,6607 & 19,9380 & 1,3885 & 1,0679 & 65,4330 & 0,7221 \\
\hline 8 & 3,7416 & 6,6722 & 5,7285 & 20,2803 & 1,3402 & 1,0286 & 63,8627 & 1,0874 \\
\hline 9 & 3,8116 & 6,8128 & 7,7624 & 20,1398 & 1,4310 & 1,0264 & 61,7785 & 1,0491 \\
\hline 10 & 3,8472 & 6,6909 & 8,0063 & 20,1333 & 1,5419 & 1,5501 & 61,0464 & 1,0310 \\
\hline 11 & 3,9131 & 7,0513 & 8,1339 & 21,1289 & 1,9326 & 1,6973 & 59,0589 & 0,9971 \\
\hline 12 & 4,0143 & 8,6243 & 9,2798 & 20,6478 & 1,9146 & 1,6366 & 56,9477 & 0,9493 \\
\hline
\end{tabular}




\section{III.7. Kelompok Transportasi, Komunikasi, dan Jasa Keuangan (TRANS)}

\section{III.7.1. Impulse Response Function Harga Kelompok Transportasi, Komunikasi, dan Jasa Keuangan}

Jika terjadi shock positif sebesar 1 S.D. pada bulan pertama ke depan dari setiap variabel yang menyebabkan peningkatan harga tertinggi pada harga kelompok TRANS adalah kelompok TRANS itu sendiri sebesar 3,05\%, kemudian PERUM 2,44\%. Hal ini menunjukkan pengaruh harga kelompok PERUM terutama dari sub-kelompok bahan bakar sangat besar pada harga kelompok TRANS, yaitu memberikan shock dengan kisaran lebih dari $2 \%$ berlangsung hingga bulan ke-3 (satu triwulan).

Selain itu, ditemukan pula bahwa harga kelompok BAMA dan MAJADI memberikan shock peningkatan harga pada kelompok TRANS cukup besar dengan range masing-masing antara 1,21\%-2,00\% dan 1,11\%-2,68\% dalam 12 bulan ke depan.

\section{Response to Generalized One S.D. Innovations}
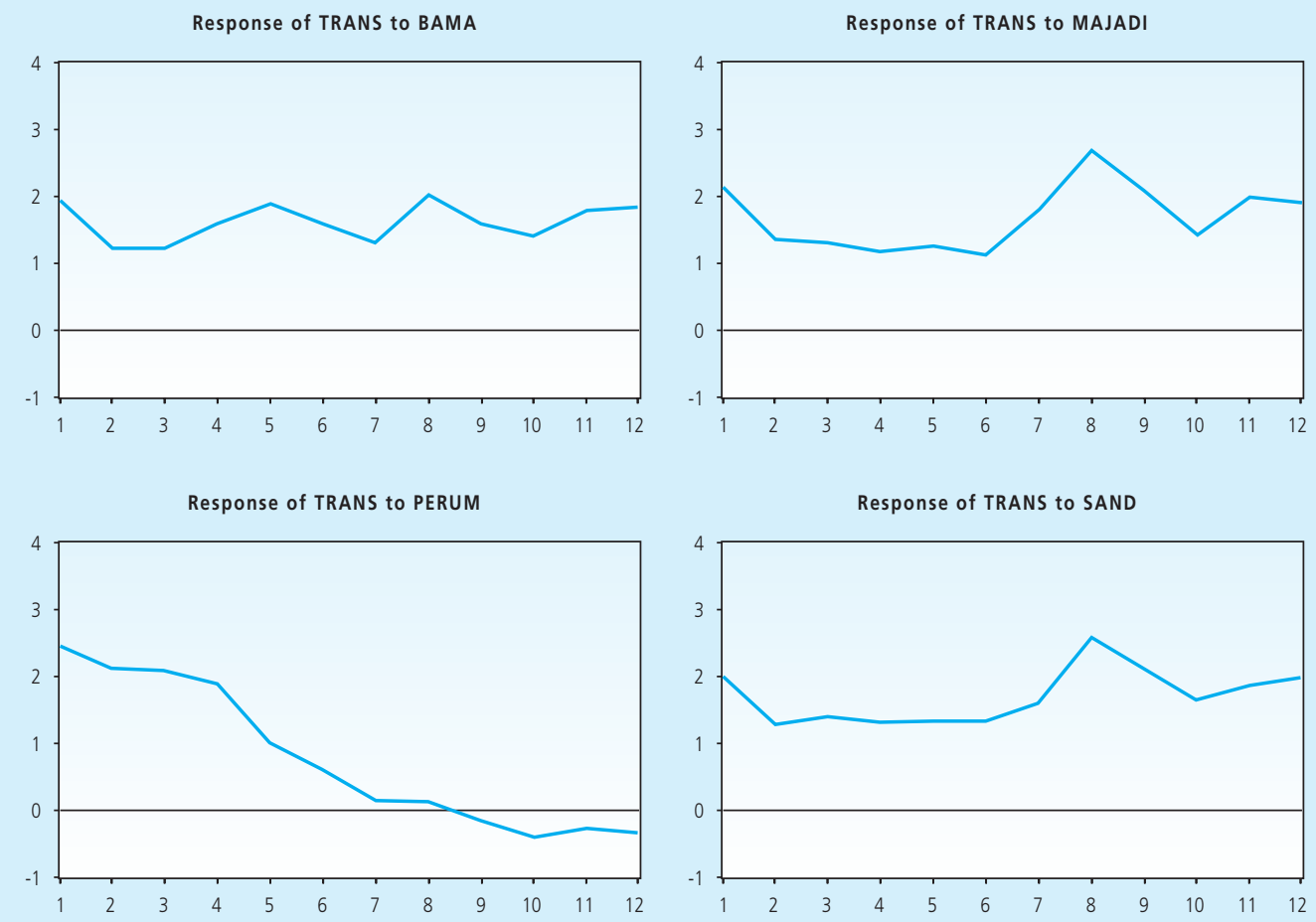

Grafik III.11

Impulse Response Function Harga Kelompok Transportasi, Komunikasi, dan Jasa Keuangan 


\section{Response to Generalized One S.D. Innovations}

Response of TRANS to KES

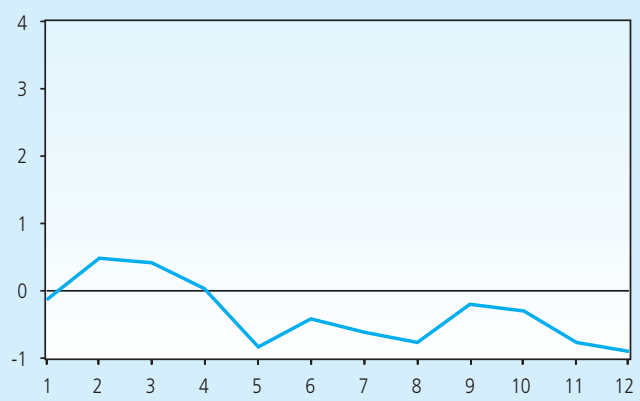

Response of TRANS to TRANS

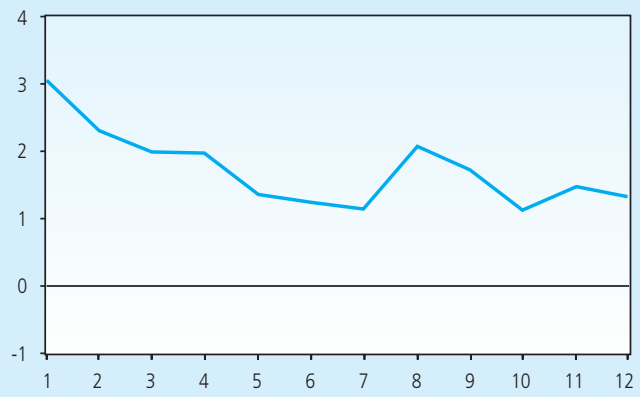

Response of TRANS to PENDIDI

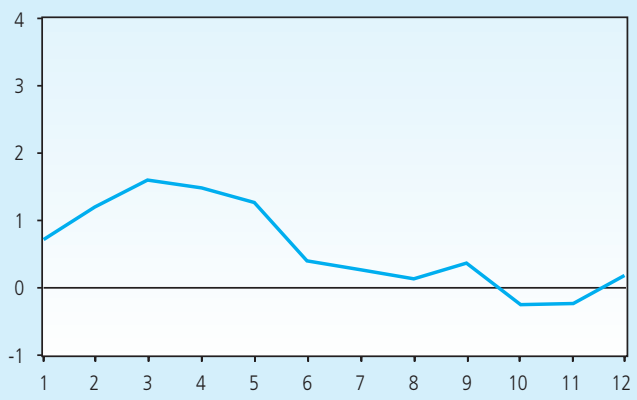

Grafik III.11

Impulse Response Function Harga Kelompok Transportasi, Komunikasi, dan Jasa Keuangan (lanjutan)

\section{Tabel III.18}

Impulse Response Function Harga Kelompok Transportasi, Komunikasi, dan Jasa Keuangan

\begin{tabular}{|c|c|c|c|c|c|c|c|}
\hline Period & BAMA & MAJADI & PERUM & SAND & KES & PENDIDI & TRANS \\
\hline 1 & 1,9358 & 2,1437 & 2,4408 & 1,9954 & $-0,1409$ & 0,7200 & 3,0486 \\
\hline 2 & 1,2072 & 1,3630 & 2,1267 & 1,2708 & 0,4798 & 1,1954 & 2,3051 \\
\hline 3 & 1,2184 & 1,3086 & 2,0903 & 1,3917 & 0,4180 & 1,5896 & 1,9840 \\
\hline 4 & 1,5841 & 1,1695 & 1,8869 & 1,3123 & 0,0319 & 1,4846 & 1,9576 \\
\hline 5 & 1,8814 & 1,2654 & 1,0068 & 1,3175 & $-0,8334$ & 1,2673 & 1,3608 \\
\hline 6 & 1,5876 & 1,1128 & 0,6067 & 1,3197 & $-0,4094$ & 0,3977 & 1,2258 \\
\hline 7 & 1,3012 & 1,8056 & 0,1358 & 1,6001 & $-0,6285$ & 0,2703 & 1,1323 \\
\hline 8 & 2,0065 & 2,6770 & 0,1324 & 2,5697 & $-0,7722$ & 0,1326 & 2,0700 \\
\hline 9 & 1,5804 & 2,0881 & $-0,1581$ & 2,1053 & $-0,2113$ & 0,3730 & 1,7187 \\
\hline 10 & 1,4020 & 1,4125 & $-0,4166$ & 1,6425 & $-0,3103$ & $-0,2536$ & 1,1099 \\
\hline 11 & 1,7810 & 1,9732 & $-0,2808$ & 1,8696 & $-0,7756$ & $-0,2382$ & 1,4729 \\
\hline 12 & 1,8417 & 1,8965 & $-0,3574$ & 1,9762 & $-0,8929$ & 0,1753 & 1,3228 \\
\hline
\end{tabular}




\section{III.7.2. Variance Decomposition Harga Kelompok Transportasi, Komunikasi, dan Jasa Keuangan}

Hasil FEDV mengkonfirmasi hasil IRF di mana komposisi penyumbang perubahan harga pada kelompok TRANS kedua terbesar adalah kelompok MAJADI dan PERUM. Hal ini berlangsung hingga 12 bulan ke depan. Kontribusi kelompok MAJADI pada range 30,17\%43,44\%, sedangkan kelompok PERUM pada range 21,29-31,15\%. Pada harga kelompok TRANS itu sendiri hanya berkisar pada range 7,26\%-18,17\%. Dengan demikian melalui tabel di atas menunjukkan bahwa harga kelompok TRANS tidak hanya secara besar dipengaruhi oleh harga kelompok PERUM yang didalamnya termasuk sub-kelompok bahan bakar, namun juga harga kelompok BAMA.

Tabel III.19

Variance Decomposition Harga Kelompok Transportasi, Komunikasi, dan Jasa Keuangan

\begin{tabular}{c|l|l|r|r|r|r|r|r} 
Period & S.E. & BAMA & MAJADI & PERUM & SAND & KES & PENDIDI & TRANS \\
1 & 3,0486 & 40,3187 & 19,0171 & 21,2930 & 1,0899 & 0,0091 & 0,1007 & 18,1715 \\
2 & 3,9745 & 32,9471 & 15,8680 & 28,3363 & 0,8499 & 1,1866 & 4,7612 & 16,0510 \\
3 & 4,7083 & 30,1742 & 14,1163 & 31,1502 & 1,3688 & 1,4347 & 10,2014 & 11,5543 \\
4 & 5,2688 & 33,1345 & 11,8569 & 30,8023 & 1,4225 & 1,2937 & 11,9691 & 9,5211 \\
5 & 5,6710 & 39,6079 & 10,5805 & 26,6328 & 1,3208 & 1,4645 & 12,0669 & 8,3267 \\
6 & 5,9266 & 43,4415 & 10,0055 & 24,5064 & 1,7460 & 1,3611 & 11,0692 & 7,8702 \\
7 & 6,3144 & 42,5164 & 13,1910 & 24,0810 & 1,8712 & 1,3024 & 9,7799 & 7,2582 \\
8 & 7,2860 & 39,5177 & 16,7879 & 22,7899 & 2,6626 & 0,9935 & 7,7985 & 9,4500 \\
9 & 7,9833 & 36,8346 & 17,4268 & 22,7303 & 3,2204 & 1,1202 & 6,5030 & 12,1647 \\
10 & 8,4388 & 35,7255 & 16,4920 & 23,5043 & 3,7272 & 1,1732 & 6,4952 & 12,8825 \\
11 & 9,0160 & 35,1993 & 16,2917 & 24,1158 & 3,5528 & 1,0281 & 6,3850 & 13,4273 \\
12 & 9,5207 & 35,3085 & 15,9386 & 25,0640 & 3,7221 & 0,9346 & 5,8813 & 13,1509 \\
& & & & & &
\end{tabular}

\section{KESIMPULAN DAN IMPLIKASI KEBIJAKAN}

\section{IV.1. Kesimpulan}

Sebagaimana disebutkan pada bagian metodologi, paper ini lebih ditujukan untuk menganalisis kondisi empiris pergerakan harga dan inflasi antar komoditi satu dengan lainnya. Diatas asumsi bahwa variabel harga yang terlibat dalam proses estimasi telah memiliki informasi yang cukup sempurna, maka berdasarkan hasil estimasi dan analisi paper ini memberikan beberapa kesimpulan sebagai berikut:

- Pergerakan harga pada kelompok bahan makanan dominan dipengaruhi oleh pergerakan harga di kelompok bahan makanan itu sendiri. Hal ini terkait dengan komposisi kelompok ini yang banyak terdiri komoditas hasil pertanian yang rentan produksinya dipengaruhi oleh 
faktor cuaca dan sifatnya yang musiman. Peningkatan harga di kelompok ini berlangsung persisten, mencapai 1-10 bulan ke depan. Selain itu, kelompok ini juga cukup besar dipengaruhi oleh harga kelompok transportasi, komunikasi, dan jasa keuangan, terutama dari sisi sub-kelompok transportasi yang mempengaruhi struktur biaya kelompok bahan makanan dalam proses pendistribusiannya.

- Pergerakan harga pada kelompok makanan jadi, minuman, rokok, dan tembakau dominan dipengaruhi oleh kelompok komoditas itu sendiri, serta tidak terlepas dari pengaruh kelompok bahan makanan yang merupakan banyak sebagai bahan baku kelompok komoditas tersebut. Selain itu, harga pada kelompok transportasi, komunikasi, dan jasa keuangan-dalam hal ini khususnya sub-kelompok transportasi-juga turut mempengaruhi kelompok komoditas tersebut.

- Pergerakan harga pada kelompok perumahan, air, listrik, gas, dan bahan bakar secara umum banyak dipengaruhi oleh pergerakan harga dirinya sendiri. Hal ini terkait di mana banyak komoditas pembentuk kelompok tersebut yang harganya ditentukan oleh pemerintah (administered prices). Dengan demikian shock harga yang terjadi tergantung pada kebijakan harga dan perubahan tarif yang ditetapkan oleh pemerintah.

- Pergerakan harga pada kelompok sandang dipengaruhi dominan oleh dirinya sendiri hanya pada satu bulan ke depan, untuk beberapa bulan selanjutnya justru banyak dipengaruhi oleh harga kelompok bahan makanan, dan kelompok makanan jadi, minuman, rokok, dan tembakau.

- Pergerakan harga pada kelompok kesehatan secara dominan dipengaruhi oleh dirinya sendiri. Selain itu juga kelompok bahan makanan dan kelompok perumahan, listrik, air, gas, dan bahan bakar mempengaruhi cukup besar kelompok komoditas tersebut.

- Pergerakan harga pada kelompok pendidikan juga secara dominan dipengaruhi oleh dirinya sendiri. Harga kelompok perumahan, listrik, air, gas, dan bahan bakar juga memberikan kontribusi yang cukup besar pada kelompok komoditas ini. Hal tersebut dapat terjadi karena operasional kelompok pendidikan tidak dapat terlepas dari kebutuhan pada kelompok perumahan, listrik, air, gas, dan bahan bakar.

- Pergerakan harga pada kelompok transportasi, komunikasi, dan jasa keuangan dipengaruhi oleh harga pada kelompok perumahan, listrik, air, gas, dan bahan bakar. Hal ini terkait dengan sub-kelompok transportasi yang tidak dapat dipisahkan pada kebutuhan di subkelompok bahan bakar. Selain itu, kelompok komoditas tersebut berdasarkan hasil estimasi juga dipengaruhi oleh harga kelompok bahan makanan. 


\section{IV.2. Implikasi Kebijakan}

- Pengendalian inflasi di daerah tidak cukup hanya dengan melalui kebijakan moneter yang bersifat skala nasional. Permasalahan inflasi di daerah banyak yang sifatnya non-moneter atau butuh koordinasi yang baik dengan Pemerintah Daerah mengenai pengendaliannya. Inflasi Sumbar sendiri sejak terjadi shock kenaikan harga BBM pada bulan Mei 2008, inflasinya selalu di atas inflasi nasional. Oleh karena itu, selain mengandalkan kebijakan ekonomi secara nasional, diperlukan pula kebijakan dari pemerintah daerah dalam pengendalian inflasi di daerah.

- Pengendalian inflasi di daerah tidak cukup hanya melakukan pengendalian secara parsial yang fokus pada kelompok komoditas tertentu yang dianggap memberikan kontribusi besar dalam pembentuk inflasi daerah. Hal ini karena sifat keterkaitan yang dimiliki antar harga kelompok komoditas pembentuk inflasi yang memiliki kontribusi pada peningkatan harga di kelompok komoditas lainnya.

- Upaya pengendalian inflasi daerah terutama pada pengendalian harga kelompok bahan makanan dengan bobot pembentuk inflasi tertinggi dengan SBH 2007 sebesar 31,35\% memerlukan kebijakan yang sifatnya struktural. Yaitu terutama dalam mendorong terjadinya perbaikan dalam pola distribusi pasokan serta dukungan infrastruktur yang memperlancar transportasi dan distribusi barang.

- Kebijakan pemerintah dalam penetapan harga berbagai komoditas seperti banyak terdapat pada kelompok perumahan, listrik, air, gas, dan bahan bakar, keputusan untuk meningkatkan harga menjadi keputusan yang sangat krusial. Shock harga yang terjadi akan cukup lama untuk menyesuaikan kembali ke tingkat keseimbangannya menuju ke harga semula, dan juga peran ke harga komoditas lainnya juga cukup besar. Dengan demikian, sebaiknya dilakukan peningkatan harganya secara bertahap dengan mempertimbangkan dampak yang terjadi pada harga di kelompok lainnya. 


\section{DAFTAR PUSTAKA}

Brodjonegoro, Bambang P.S., Telissa Falianty, dan Beta Y. Gitaharie, "Determinant Factors of Regional Inflation in Decentralized Indonesia," Journal of Economics and Finance in Indonesia, Vol. 53 (1), pp. 1-31.

Carlino, Gerald dan Robert Defina, "The Differential Regional Effects of Monetary Policy," The Review of Economics and Statistics, Vol. 80, No.4, November 1998. pp.572-587.

Clements, Kenneth W. dan H.Y. Izan, "The Measurement of Inflation: A Stochastic Approach," Journal of Business and Economic Statistics, Vol. 5, No. 3 (Jul, 1987), pp. 339-350.

Engle, R.F., dan C.W. Granger, "Co-integration and Error Correction: Representation, Estimation and Testing," Econometrica, Vol. 55, 1987, pp. 251-276.

Gordon, Robert J., "The Time-Varying NAIRU and its Implications for Economic Policy". Journal of Economic Perspectives - Vol. 11, No.1, 1997, pp. 11-32.

Gujarati, Damodar, Basic Econometrics, Fourth-Edition. (New York: The McGraw-Hill Companies, 2004).

Johansen, S., "Estimation and Hypothesis Testing of Cointegrated Vectors in Gaussian VAR Models," Econometrica, No.59, Vol.6, 1991, pp. 1551-1580.

Johnston, Jack dan John DiNardo, Econometric Methods, 4th ed. (New York : McGraw-Hill Companies, 1997).

Madjardi, Fadjar, "Administered Price dan Pola Penetapan Harga BBM," Catatan Riset, Direktorat Kebijakan Moneter, Bank Indonesia, Juli 2002.

Sims, Christopher A., "Macroeconomic and Reality," Econometrica, Vol. 48, 1980, pp. 1-48. Stock, James H. dan Mark W. Watson, "Implications of Dynamic Factor Models for VAR Analysis," Working Paper 11467, National Bureau of Economic Research, Juni 2005.

Wimanda, Rizki E., "Regional Inflation in Indonesia: Characteristic, Convergence, and Determinants," Bank Indonesia Working Paper, No.13, Oktober 2006. 